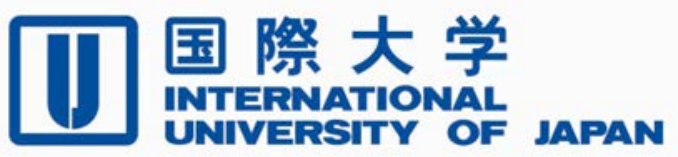

Economics \& Management Series

EMS-2020-04

\title{
Urban and Rural Dimensions of the Role of Education in Inequality: A Comparative Analysis between Indonesia, Myanmar, and the Philippines
}

Takahiro Akita

IUJ Research Institute,

International University of Japan

Sachiko Miyata

Graduate School of Business Administration

and College of Business Administration,

Ritsumeikan University

October 2020

IUJ Research Institute

International University of Japan

These working papers are preliminary research documents published by the IUJ research institute. To facilitate prompt distribution, they have not been formally reviewed and edited. They are circulated in order to stimulate discussion and critical comment and may be revised. The views and interpretations expressed in these papers are those of the author(s). It is expected that the working papers will be published in some other form. 
Urban and Rural Dimensions of the Role of Education in Inequality: A Comparative Analysis between Indonesia, Myanmar, and the Philippines*

\author{
Takahiro Akita \\ Visiting Research Fellow, International University of Japan \\ e-mail: akita@iuj.ac.jp \\ and \\ Sachiko Miyata \\ Professor, Graduate School of Business Administration \\ and College of Business Administration, \\ Ritsumeikan University \\ e-mail: miyata@fc.ritsumei.ac.jp
}

Short running title: Urban and rural dimensions of the roles of education in inequality

Keywords: urban and rural dimensions, educational inequality, expenditure inequality, hierarchical decomposition of Theil indices, comparative analysis

JEL code: I24, I25, O15

\footnotetext{
* The authors are grateful to the Japan Society for the Promotion of Science (Grant-in-Aid for Scientific Research 15KK0096, 18K01589, and 18K01635).
} 


\section{Urban and Rural Dimensions of the Role of Education in Inequality: A Comparative Analysis between Indonesia, Myanmar, and the Philippines}

\section{Introduction}

Education is the key to national development and considered to be one of the principal means of alleviating poverty and inequality (De Janvry and Sadoulet, 2016). It is a major determinant of income, and a positive relationship is likely to exist between inequality in educational attainment and income inequality. Whether the expansion of education has narrowed or widened income inequality is of policy relevance in developing countries. Asian developing countries have made significant progress in education over the last decades. However, many of them still suffer from high poverty and inequality. Against this background, this study attempts to analyze the roles of education in the distribution of economic well-being in Asian developing countries that have developed relatively rapidly over the last two decades. The analysis is conducted in an urban and rural dual framework, since disparity between urban and rural areas is one of the main determinants of the distribution of economic wellbeing and there is a large difference in socioeconomic structure between urban and rural areas (Eastwood and Lipton, 2004; Shorrocks and Wan, 2005; Kanbur and Zhuang, 2013).

This study uses data from nation-wide household surveys conducted by central statistical offices. As a measure of economic well-being, it uses expenditure rather than income for the following reasons (Akita, Lukman and Yamada, 1999). First, expenditure data are usually more reliable than income data in developing countries since households in higher income groups tend to underreport their incomes. Second, welfare levels are likely to be better indicated by current expenditure than by current income. We should note, however, that expenditure inequality is usually smaller than income inequality since higher income households tend to save a larger proportion of their incomes.

We choose Indonesia, Myanmar and the Philippines as a sample of Asian developing countries and make a comparison among these countries in terms of the roles of education in the distribution of economic well-being. These three countries belong to the Association of South East Asian Nations (ASEAN) and are among the middle-income countries whose population exceeds 50 million. Indonesia is the world's largest archipelagic country and also the world's largest Muslim country. It comprises more than 13,000 islands. Meanwhile, the Philippines is the world's second largest archipelagic country, which consists of more than 
7,000 islands. These two countries are diverse in terms of geography, natural resource endowments, ethnicity and culture; Indonesia and the Philippines accommodate, respectively, 300 and 110 ethnic groups. Myanmar is bordered by Bangladesh, China, India, Laos, and Thailand and joined ASEAN in 1997. In terms of land area, the country is the largest among the mainland ASEAN countries (Cambodia, Laos, Malaysia, Myanmar, Singapore, Thailand and Vietnam). Myanmar is also ethnically diverse with more than 100 ethnic groups.

Among the three countries, Indonesia has the largest population with 258 million in 2015, and 56\% of them are living in the island of Java where the city of Jakarta is located (Table 1). The Philippines and Myanmar follow next with 102 million and 53 million, respectively. In the Philippines, 53\% of the population are in the island of Luzon, where the city of Manila is located. Meanwhile, in Myanmar, around 14\% of the population live in the region of Yangon, the largest region in the country. Indonesia is the most developed country in terms of per capita GDP, whose per capita GDP is 1.5 times that of the Philippines and 2.9 times that of Myanmar (Table 1). In Indonesia and the Philippines, the manufacturing share of total GDP has been declining gradually over the last two decades, while in Myanmar, it has been rising rapidly. As a result, these three countries registered the same level of the manufacturing share of total GDP in 2015. It seems that Indonesia and the Philippines have undergone premature output deindustrialization since the 2000s (Rodrik, 2016).

\section{Table 1}

Education system differs considerably among these three countries. In Indonesia, the formal education system consists of four levels: preprimary; basic compulsory education including six years of primary education (starting at seven years of age) and three years of junior secondary education; three years of senior secondary education; and tertiary education (one to four years of diploma programs and international standard bachelor's, master's and doctoral programs) (Di Gropello, 2011a). At each level of education, an Islamic counterpart is available to students, which serves as an alternative to the general education system (Di Gropello, 2011a). In Myanmar, the formal education system encompasses preschool, basic compulsory education (five years of primary education starting at five years of age inclusive of kindergarten), four years of junior secondary education, two years of senior secondary education, and tertiary education (bachelor's, master's and doctoral programs) (UNESCO, 2011; Hayden and Martin, 2013). In addition to formal education, monastic schools run by Buddhist monks are available for needy and orphans at the primary and secondary levels (Hayden and Martin, 2013). In the Philippines before 2012, the formal education system 
consisted of preprimary, basic compulsory education including six years of primary education (starting at six years of age) and four years of secondary education, two years of postsecondary technical and vocational education programs or tertiary education (bachelor's, master's and doctoral programs) (Di Gropello, 2011b). Since 2013, however, basic compulsory education has been expanded to 13 years from kindergarten to senior secondary education (one year of kindergarten starting at five years of age, six years of primary education, and two years of junior and four years of senior secondary education) (UNESCO, 2015).

All three countries have made steady progress in education over the last two decades; their gross primary education ratios have exceeded $100 \%$ since the early 1990 s. As shown in Figure 1, in the period from 2001-2015, the Philippines has raised its gross secondary enrollment ratio from $75 \%$ to $88 \%$, while Indonesia has increased its ratio from 55\% to $86 \%$. Though the ratio is much smaller, Myanmar has increased its ratio from $38 \%$ to $52 \%$. As shown in Figure 2, however, the progress of tertiary education varies among the three countries. While Indonesia has made substantial progress in tertiary education by raising its gross tertiary enrollment ratio from 14\% to 33\%, Myanmar increased its ratio merely from $11 \%$ to $14 \%$ and the Philippines from 31\% to 35\%. In Myanmar, tertiary education is still underdeveloped, and universities are concentrated in major cities such as Yangon and Mandalay. The gross tertiary enrollment ratio is the second lowest among ASEAN counties next to Laos.

\section{Figures 1 and 2}

This study first analyzes inequality in the number of years of education among households (hereafter, educational inequality) by conducting an inequality decomposition analysis by urban and rural sectors using the Gini coefficient. It then employs the BlinderOaxaca decomposition method to examine the effects of education on urban-rural disparity in mean per capita expenditure (hereafter, expenditure inequality) (Blinder, 1973; Oaxaca, 1973). Finally, using the two-stage hierarchical Theil decomposition method developed by Akita and Miyata (2013), this study analyzes the role of education in expenditure inequality after removing the effect of urban-rural differences in educational endowments on expenditure inequality. It should be noted that to measure expenditure inequality, the Theil index $T$ is employed. ${ }^{1}$ But, to measure educational inequality, the Gini coefficient is used

\footnotetext{
1 The formula of the Theil index $T$ will be presented in the methodology section. In this study, another Theil index, the Theil index $L$, is also used to perform a hierarchical inequality decomposition analysis. But the result
} 
since a household with no education is given 0 year of education and thus it is not possible to calculate the Theil index $T$. These inequality measures satisfy several desirable properties such as anonymity principle, mean independence, population-size independence and the Pigue-Dalton transfer principle (Anand, 1983; Haughton and Khandker, 2009). Moreover, the Theil index $T$ is additively decomposable by population sub-groups, that is, total inequality can be expressed as the sum of the within- and between-group inequality components (Bourguignon, 1979; Shorrocks, 1980). However, the Gini coefficient cannot be decomposed in this way, since the residual term emerges when the distributions of population sub-groups overlap (Lambert and Aronson, 1993; Dagum, 1997).

\section{Literature Review}

A spate of studies has been conducted to analyze the relationship between the level of education, educational inequality and income or expenditure inequality. Some of these studies include Knight and Sabot (1983), Ram (1989, 1990), Park (1996), Chu (2000), De Gregorio and Lee (2002), Lin (2006) and Abdullah, Doucouliagos and Manning (2015). Based on a dataset of around 100 countries, Ram (1990) found that there is an inverted-U shaped relationship between the level of educational attainment and educational inequality, that is, educational inequality first increases, attains the peak and then declines with educational expansion. Ram (1990) claimed that educational inequality may decline monotonically with educational expansion for less-developed countries which have already reached a certain level of educational attainment and have adopted free and universal primary education. Using a dataset of 59 countries, Park (1996) found that a higher level of educational attainment tends to reduce income inequality and educational inequality is positively associated with income inequality. Based on a panel dataset of more than 100 countries for the period from 1960 to 1990, De Gregorio and Lee (2002) found that higher educational attainment and more equal distribution of education appear to play a significant role in equalizing income distribution. Based on 64 empirical studies, Abdullah, Doucouliagos and Manning (2015) performed a meta regression analysis to investigate the effect of education on inequality and found that education appears to be an effective means for reducing inequality.

In an urban-rural dual framework, our study analyzes the role of education in expenditure inequality using the Theil decomposition method. The studies that employed the

is similar to the one by the Theil index $T$ qualitatively and thus it is not presented. 
Theil decomposition method include Ikemoto (1985) for Malaysia, Glewwe (1986) for Sri Lanka, Ikemoto and Limskul (1987) for Thailand, Ching (1991) for the Philippines, Tsakloglou (1993) for Greece, Estudillo (1997) for the Philippines, Akita, Lukman and Yamada (1999) for Indonesia, Kanbur and Zhang (1999) for China, Parker (1999) for U.K., Dickey (2001) for Great Britain, Liu (2001) for Vietnam, Gray, Mills \& Zandvakili (2003) for Canada, Mukhopadhaya (2003) for Singapore, Rao, Banerjee and Mukhopadhaya (2003) for Singapore, Motonishi (2006) for Thailand, Tang and Petrie (2009) for Australia, and Akita and Miyata (2013) for Indonesia. According to the studies that examined the role of education in inequality using the Theil decomposition method, education is one of the major determinants of income or expenditure inequality by accounting for around $20-40 \%$ of overall inequality. On the other hand, according to the Theil decomposition studies that analyzed the role of urban and rural locations in inequality, urban-rural disparity explains around $10-30 \%$ of overall income or expenditure inequality. It should be noted that unlike most previous studies which employed the one-stage Theil decomposition method, our study uses the two-stage hierarchical Theil decomposition method developed by Akita and Miyata (2013).

In Indonesia, there are many studies that have analyzed expenditure or income inequality using data from the National Socioeconomic Survey (Susenas) or the Family Life Survey (IFLS). They include Hughes and Islam (1981), Islam and Khan (1986), Asra (1989), Akita and Lukman (1999), Akita, Lukman and Yamada (1999), Asra (2000), Akita and Miyata (2008), Akita and Miyata (2013), Hayashi, Kataoka and Akita (2014), Yusuf, Sumner and Rum (2014) and Chongvilaivan and Kim (2016). Among these studies, Akita and Miyata (2008), Akita and Miyata (2013) and Hayashi, Kataoka and Akita (2014) focused on education and examined the role of education in expenditure inequality in an urban and rural framework using the Theil decomposition method. Akita and Miyata (2008) used household expenditure data from the 1996, 1999 and 2002 Susenas to investigate the evolution of expenditure inequality associated with urbanization and educational expansion. According to them, widening inequality among urban households with higher levels of education, together with urbanization and educational expansion, appears to have contributed to the rise of overall inequality over the period 1996-2002. Hayashi, Kataoka and Akita (2014) used household expenditure data from the panel Susenas to analyze the role of education in expenditure inequality from spatial perspectives over the period 2008-2010. Using several decomposition methods, they found that differences in educational attainment levels appear 
to have played an important role in expenditure inequality within urban areas and between urban and rural areas. Finally, based on the 1987, 1990 and 1993 Susenas, Akita, Lukman and Yamada (1999) examined the roles of location, age, education, gender and household size in expenditure inequality using the one-stage Theil decomposition method. They found that expenditure disparity across educational groups accounted for more than $30 \%$ of overall expenditure inequality as measured by the Theil index $T$.

In Myanmar, most previous studies that used data from the Household Income and Expenditure Surveys (HIES) have focused on poverty, and studies on inequalities are scarce. Some of these studies include Lar, et al. (2012), Shaffer (2015), Teerawichitchainan and Knodel (2015), Wagle (2016), World Bank (2017) and Mohanty et al. (2018). Using a new household-level dataset for the Mawlamyine township (capital city of the Mon state), Lar, et al. (2012) analyzed the level, causes and consequences of poverty in one of the most promising areas for economic development. By estimating the incidence, depth and severity of poverty in rural, semi-urban and urban sections of the township, they found that semiurban areas had the highest amount of absolute poverty. They also measured income and expenditure inequality using the Gini coefficient and found that urban areas had the largest inequality. They argued that poverty may most effectively be reduced by education, remittances and motorcycle ownership. Based on a poverty and vulnerability assessment survey carried out in 2013, Mohanty et al. (2018) estimated multidimensional poverty in the mountainous states of Chin and Shan and observed that almost half the population in Shan and three-quarters in Chin were multidimensionally poor and multidimensional poverty is negatively associated with education. They urged the need for a geographical focus for poverty alleviation in Myanmar.

In the Philippines, studies on the distribution of economic well-being using data from the Family Income and Expenditure Surveys (FIES) include Ching (1991), Estudillo (1997), Balisacan and Pernia (2002), Balisacan and Fuwa (2003, 2004), Pernia (2008), Son (2008), Mapa, Balisacan, Briones and Albis (2009), and Seriño (2014). Among these studies, Ching (1991), Estudillo (1997) and Seriño (2014) analyzed the roles of household attributes in income inequality using the one-stage Theil decomposition method. Using data from the 1985 FIES, Ching (1991) considered location, education, age, gender and household size as major determinants of income inequality and found that income disparity across educational groups of household head was the largest contributor to overall income inequality by accounting for $39 \%$ of overall inequality as measured by the Theil index $T$. On the other 
hand, Estudillo (1997) used data from the 1971 and 1991 FIES in addition to the 1985 FIES to analyze the roles of location, education and age in income inequality and obtained results similar to Ching (1991), where the contribution of income disparity across educational groups of household head was the largest amounting to $25-35 \%$ of overall income inequality as measured by the Theil index T. Based on the 2000 and 2006 FIES, Seriño (2014) considered location, education and age as main determinants of income inequality in Eastern Visayas, one of the 13 regions of the Philippines. The study found that the contribution of income disparity across educational groups of household head was very large at around $40 \%$ of overall inequality as measured by the Theil index $T$.

\section{Method and The Data}

\subsection{Methods}

\section{Decomposition of Education Gini Coefficient by Location (Urban and Rural Sectors)}

To examine educational inequality, we conduct an inequality decomposition analysis by urban and rural sectors using the Gini coefficient. Unlike the Theil index $T$, the Gini coefficient fails to decompose additively into within- and between-group components since an extra term emerges if the distributions of educational attainment for the urban and rural sectors overlap. Nevertheless, we employ the Gini coefficient to conduct a decomposition analysis of educational inequality by urban and rural sectors, since there is a certain overlap between the urban and rural sectors in the distribution of educational attainment and it is interesting to know how this overlap evolves with the expansion of education.

Suppose that there are $N$ households in a country, who are classified into the urban and rural sectors (sectors 1 and 2, respectively), and the educational level of a household is measured by the number of years of education completed by its household head. We let $e_{i h}, \mu$ and $N_{i}$ be the number of years of education of household $h$ in sector $i$, the mean number of years of education of all households, and the total number of households in sector $i .^{2}$ Then, overall educational inequality can be measured by the following Gini coefficient.

$$
G=\frac{1}{2 N^{2} \mu} \sum_{i=1}^{2} \sum_{j=1}^{2} \sum_{h=1}^{N_{i}} \sum_{k=1}^{N_{j}}\left|e_{i h}-e_{j k}\right|
$$

The education Gini defined by equation (1) can be additively decomposed into the within-sector Gini $\left(G_{W S}\right)$, the between-sector Gini $\left(G_{B S}\right)$ and the residual term $\left(G_{R}\right)$ as follows (for details, see Lambert and Aronson, 1993; Dagum, 1997).

\footnotetext{
2 Table A1 in the appendix presents the way how to determine the number of years of education completed by the head of household.
} 


$$
G=G_{W S}+G_{B S}+G_{R}
$$

In equation (2), $G_{W S}$ is a weighted average of the Gini coefficients for the urban and rural sectors, which is given by

$$
G_{W S}=\sum_{i=1}^{2} p_{i} s_{i} G_{i},
$$

where $p_{i}, s_{i}$, and $G_{i}$ are, respectively, the sector i's share of households, the sector $i$ 's share of the number of years of education, and the Gini coefficient of sector $i$. On the other hand, $G_{B S}$ is the Gini coefficient that would be obtained if each household in a sector was given the mean number of years of education for the sector. $G_{B S}$ is defined as

$$
G_{B S}=\frac{1}{2 N^{2} \mu} \sum_{i=1}^{2} \sum_{j=1}^{2} \sum_{h=1}^{N_{i}} \sum_{k=1}^{N_{j}}\left|\mu_{i}-\mu_{j}\right|=\frac{1}{2 \mu} \sum_{i=1}^{2} \sum_{j=1}^{2} p_{i} p_{j}\left|\mu_{i}-\mu_{j}\right|
$$

where $\mu_{i}$ is the mean number of years of education for sector $i$. We should note that the residual term, $G_{R}=G-G_{W S}-G_{B S}$, is zero if the distributions of years of education for the urban and rural sectors do not overlap; but takes a positive value if they overlap.

\section{Blinder-Oaxaca Decomposition Analysis}

To analyze the extent to which educational endowments explain the difference in mean per capita expenditure between the urban and rural sectors, we perform a Blinder-Oaxaca decomposition analysis (Blinder, 1973; Oaxaca, 1973). Consider the linear regression model for the urban and rural sectors (sectors 1 and 2, respectively),

$$
y_{k}=\boldsymbol{X}_{k}^{\prime} \boldsymbol{\beta}_{k}+e_{k} \quad E\left(e_{k}\right)=0
$$

where $y_{k}, \boldsymbol{X}_{k}, \boldsymbol{\beta}_{k}$, and $e_{k}$ are, respectively, the natural log of per capita expenditure, a vector of explanatory variables, a vector of coefficients associated with explanatory variables, and the error term. If we let $\widehat{\boldsymbol{\beta}}_{k}, \widehat{\boldsymbol{\beta}}^{*}$ and $\overline{\boldsymbol{X}}_{k}$ be, respectively, a vector of the least-squares estimates for $\boldsymbol{\beta}_{k}$ obtained separately from the urban and rural samples, a vector of the leastsquares estimates of the coefficients obtained from the pooled sample of urban and rural households, and the estimate for $E\left(\boldsymbol{X}_{k}\right)$, then the estimated urban-rural difference in mean per capita expenditure is given by:

$$
\widehat{D}=\bar{y}_{1}-\bar{y}_{2}=\left(\overline{\boldsymbol{X}}_{1}-\overline{\boldsymbol{X}}_{2}\right)^{\prime} \widehat{\boldsymbol{\beta}}^{*}+\left(\overline{\boldsymbol{X}}_{1}^{\prime}\left(\widehat{\boldsymbol{\beta}}_{1}-\widehat{\boldsymbol{\beta}}^{*}\right)+\overline{\boldsymbol{X}}_{2}^{\prime}\left(\widehat{\boldsymbol{\beta}}^{*}-\widehat{\boldsymbol{\beta}}_{2}\right)\right) .
$$

This is the twofold decomposition equation suggested by Newmark (1988). The first term in equation (3) is the part that is explained by urban-rural differences in the explanatory variables (endowments effect), while the second term is the unexplained part.

In the regression model, we include, as explanatory variables, years of education, age, age squared, household size, and gender. For Myanmar, another explanatory variable, unemployment, is added, while for the Philippines, another explanatory variable, agriculture, 
is added. Unemployment is a dummy variable, where unemployment for a household is given one if the household head is unemployed. Agriculture is also a dummy variable, where agriculture for a household is given one if the household head is employed in the agricultural sector.

\section{Two-Stage Hierarchical Decomposition of Expenditure Inequality by the Theil Index T}

To investigate the roles of education in expenditure inequality in an urban-rural dual framework, we conduct a two-stage hierarchical inequality decomposition analysis by location and education using the Theil index $T$. In this analysis, all households are first classified into the urban and rural sectors and then, households in each of these sectors are classified into education groups.

We let $y_{i j k}, Y, N_{i j}$, and $m$ be, respectively, the per capita expenditure of household $k$ in education group $j$ in sector $i$, total per capita expenditure of all households, the number of households in education group $j$ in sector $i$, and the number of education groups. Then overall inequality in per capita expenditure is given by the Theil index $T$ as follows:

$$
T=\sum_{i=1}^{2} \sum_{j=1}^{m} \sum_{k=1}^{N_{i j}}\left(\frac{y_{i j k}}{Y}\right) \log \left(\frac{y_{i j k} / Y}{1 / N}\right)
$$

Next, we let $Y_{i j}$ and $Y_{i}$ denote, respectively, the total per capita expenditure of households in education group $j$ in sector $i$ and the total per capita expenditure of households in sector $i$. Then, the Theil index $T$ in equation (4) can be decomposed hierarchically into the between-sector inequality component $\left(T_{B S}\right)$, the within-sector between-group inequality component $\left(T_{W S B G}\right)$, and the within-sector within-group inequality component $\left(T_{W S W G}\right)$ as follows:

$$
\begin{aligned}
T & =T_{B S}+\sum_{i=1}^{2}\left(\frac{Y_{i}}{Y}\right) T_{i} \\
& =T_{B S}+\sum_{i=1}^{2}\left(\frac{Y_{i}}{Y}\right) T_{B G i}+\sum_{i=1}^{2} \sum_{j=1}^{m}\left(\frac{Y_{i j}}{Y}\right) T_{i j} \\
& =T_{B S}+T_{W S B G}+T_{W S W G}
\end{aligned}
$$

where $T_{i}, T_{B G i}$ and $T_{i j}$ are, respectively, inequality within sector $i$, inequality between education groups in sector $i$, and inequality within education group $j$ in sector $i$. Equation (5) presents the two-stage hierarchical inequality decomposition equation for location and education (Akita and Miyata, 2013).

We should note that the two-stage nested Theil decomposition method, developed by Akita (2003), is similar to equation (5). However, it is based on district-level GDP data rather 
than household-level data and considers a natural hierarchical structure, that is, regionprovince-district, in which each region is composed of a different set of provinces and each province consists of a different set of districts. By contrast, in equation (5), the urban and rural sectors have the same set of education groups.

In the two-stage hierarchical decomposition, the order of decomposition can be reversed, that is, overall inequality can be decomposed hierarchically into the between-group inequality component $\left(T_{B G}\right)$, the within-group between-sector inequality component $\left(T_{W G B S}\right)$, and the within-group within-sector inequality component $\left(T_{W G W S}\right)$ as follows:

$$
T=T_{B G}+T_{W G B S}+T_{W G W S}
$$

We should note that $T_{W G W S}$ in equation (6) is the same as $T_{W S W G}$ in equation (5). In the hierarchical inequality decomposition method, therefore, the order of decomposition matters. In order to cope with this problem, Tang and Petrie (2009) proposed an alternative multivariate decomposition framework, that is, the non-hierarchical decomposition method, in which the Theil index is decomposed non-hierarchically, that is, simultaneously with respect to some nominal scaled variables such as location, education, gender, ethnicity and age. In the context of inequality decomposition by location and education, the nonhierarchical decomposition equation is given by

$$
T=T_{B S}+T_{B G}+T_{I S G}+T_{W S W G}
$$

where $T_{I S G}$ is the sector-group interaction term. Since we have $T_{W S B G}=T_{B G}+T_{I S G}$ from equations (5) and (7), the interaction term is obtained by $T_{I S G}=T_{W S B G}-T_{B G}$. We should note, however, that the non-hierarchical decomposition method is unable to examine the difference in the structure of educational attainment between the urban and rural sectors, even though it can suggest, based on an interaction term, the significance of the difference in educational endowments between them. In contrast, the hierarchical decomposition method can analyze the difference in the structure of educational attainment by performing a one-stage decomposition analysis by education for each sector.

\subsection{The Data}

Table 2 presents the sample sizes of nation-wide household surveys in Indonesia, Myanmar and the Philippines used by this study. It also provides the distribution of households across educational groups in urban and rural areas and the shares of urban and rural households. ${ }^{3}$ The sample sizes are large enough to estimate inequalities by educational groups in urban

\footnotetext{
3 The distributions of households are estimated using sampling household weights.
} 
and rural areas. In Indonesia, the National Socioeconomic Survey (Susenas) has been conducted by the Central Bureau of Statistics since 1963. This study analyzes data from the 2000, 2006 and 2011 Susenas. In Indonesia, households are classified into the primary, secondary and tertiary education groups in terms of the education levels of their household heads. ${ }^{4}$ The primary education group includes households whose heads have either no education, incomplete primary education or primary education. The secondary group consists of households whose heads completed junior or senior secondary education, whereas the tertiary group includes households whose heads have completed one-, two- or three-year junior college (Diploma 1, 2, 3), four-year university/college (Diploma 1 and bachelor's degree), master's degree, or doctor’s degree program.

\section{Table 2}

In Myanmar, the Household Income and Expenditure Survey (HIES) has been conducted every four to six years since 1997 by the Central Statistical Organization of the Ministry of Planning and Finance in collaboration with the United Nations Development Program. ${ }^{5}$ This study uses data from the 2006 and 2012 HIES. In Myanmar, households are classified into five groups, that is, no education, pre-primary, primary, secondary and tertiary education groups since the no and pre-primary education groups together constitute more than $40 \%$ of households. The pre-primary education group includes households whose heads have no education but literate, monastic education or incomplete primary education. The secondary group includes households whose heads have junior or senior secondary education, while the tertiary group includes households whose heads have vocational education, bachelor's, master's or doctor's degrees. It should be noted that in the HIES questionnaire, no distinction is made between bachelor's, master's and doctor's degree programs.

In the Philippines, the Family Income and Expenditure Survey (FIES) has been undertaken every three to six years since 1957 by the National Statistical Office. This study uses data from the 2000 and 2006 FIES. Like Indonesia, households are classified into the primary, secondary and tertiary education groups. The primary education group includes households whose heads have no education, pre-primary education or primary education. The secondary group includes households whose heads have incomplete secondary or

\footnotetext{
4 See Table A1 in the appendix for the classifications of households in Indonesia, Myanmar and the Philippines.

5 Since 2015, the name of the survey has been changed to the Myanmar Living Condition Survey.
} 
secondary education, while the tertiary group includes households whose heads have vocational education, bachelor's, master's or doctor's degrees.

\section{Empirical Results}

\subsection{Decomposition of Education Gini by Location (Urban and Rural Sectors)}

Before examining the roles of education in expenditure inequality, it is instructive to analyze educational inequality since a positive relationship is likely to exist between educational inequality and expenditure inequality. Table 3 presents the result of the decomposition of education Gini by urban and rural locations.

\section{Table 3}

In Indonesia, the mean level of educational attainment has increased steadily in both urban and rural areas (see Table 2). In 2000, the mean years of education in the urban and rural sectors were, respectively, 8.3 and 5.1 years; but they have increased gradually to 9.2 and 6.3 years in 2011. We should note that the speed of educational expansion has been faster in rural than urban areas; thus, the urban-rural ratio in mean years of education has declined to 1.46 in 2011 from 1.63. Nonetheless, a noticeable educational disparity still existed between the urban and rural sectors. Overall educational inequality has decreased gradually from 0.37 to 0.33 . The expansion of secondary education appears to have not only reduced educational disparity between the urban and rural sectors but also educational inequality within the rural sector. Their combined contribution to overall educational inequality has thus declined from $60 \%$ to $49 \%$. Meanwhile, the contribution of the residual term, which represents the overlap in the distribution of educational attainment between the urban and rural sectors, has risen from $21 \%$ to $25 \%$. The urban sector has a much smaller educational inequality than the rural sector. Since its inequality has remained almost constant, its contribution to overall educational inequality has increased from $18 \%$ to $26 \%$.

In Myanmar, one of the peculiar phenomena is that the pre-primary and primary education groups have raised their population shares, while the secondary education group has lowered its share in both urban and rural sectors (see Table 2). As a result, the mean years of education have declined slightly from 5.6 years to 5.4 years. Due mainly to the expansion of pre-primary and primary education, overall educational inequality has declined from 0.35 to 0.32 . The expansion was more prominent in the rural sector than in the urban sector; thus, rural educational inequality has declined notably from 0.35 to 0.30 . In 2012, it was slightly smaller than urban educational inequality since urban inequality has remained constant. However, since the rural sector had a much larger population share, rural inequality 
accounted for $35 \%$ of overall educational inequality. The contribution of the urban-rural disparity to overall educational inequality has risen from $25 \%$ to $28 \%$. By contrast, the contribution of the residual term, which shows the overlap in the distribution of educational attainment between the urban and rural sectors, has declined from 25\% to $23 \%$.

In the Philippines, the mean level of educational attainment has risen in both urban and rural areas, where the primary education group has lowered its population share while the secondary and tertiary groups have raised their shares (see Table 2). In 2000, the mean years of education in the urban and rural sectors were, respectively, 9.0 and 6.3 years; but they increased to 9.2 and 6.6 years in 2006. With the expansion of secondary education, urban and rural educational inequalities have both declined, though their contributions to overall inequality have remained almost constant, respectively, at 23\% and $23-24 \%$. Since the expansion of secondary and tertiary education was slightly faster in the rural than in the urban sector, urban-rural educational disparity has also decreased. Overall educational inequality has thus declined, though slightly from 0.29 to 0.28 by the Gini coefficient.

In sum, overall educational inequality has declined in all three countries over the study periods. In Indonesia, declining rural inequality induced by the expansion of secondary education contributed to reducing overall educational inequality, while in Myanmar, declining rural inequality induced by the expansion of pre-primary and primary education contributed to the decrease in overall inequality. On the other hand, declining urban and rural inequalities brought about by the expansion of secondary education contributed equally to the reduction of overall inequality. In Indonesia, secondary education has expanded more rapidly in rural than in urban areas. This has not only reduced rural educational inequality but also narrowed educational disparity between the urban and rural sectors.

\subsection{Blinder-Oaxaca Decomposition Analysis}

We found in the previous subsection that the expansion of compulsory education appears to have reduced overall educational inequality in all three countries. In this subsection, we analyze the role of education in urban-rural disparity in mean per capita expenditure using the Blinder-Oaxaca decomposition method. Table 4 presents the result. In all three countries, the urban-rural difference of educational endowments has been the major determinant of urban-rural difference in mean per capita expenditure as it accounted for around 30-40\% of the expenditure difference. This suggests that narrowing urban-rural educational gap is the key to reduce the expenditure disparity. As discussed previously, primary education has been compulsory in all three countries; thus, its gross enrollment ratio has exceeded $100 \%$. 
However, many rural households have completed only primary education or less. Particularly in Myanmar, more than half of rural households have not completed primary education. Thus, promoting and strengthening primary education is essential in rural Myanmar to decrease urban-rural educational gap; this would in turn reduce urban-rural expenditure disparity. On the other hand, in Indonesia and the Philippines, promoting and strengthening secondary education is necessary in rural areas to reduce urban-rural educational gap in addition to improving the quality of primary education.

\section{Table 4}

\subsection{Hierarchical Decomposition of Expenditure Inequality by Location and Education}

Table 5 presents, hierarchically, the results of an inequality decomposition analysis by urban and rural locations and an inequality decomposition analysis by educational groups in each of the urban and rural sectors, where the contributions are all measured against overall expenditure inequality rather than urban and rural expenditure inequalities. ${ }^{6}$

\section{Table 5}

\subsubsection{Indonesia}

In Indonesia, overall expenditure inequality has increased prominently from 0.20 to 0.32 over the study period (see Table 5a). According to the expenditure shares of decile groups, the richest decile group has raised its expenditure share significantly from $26.8 \%$ in 2000 to 32.2\% in 2011, while most other decile groups lost their shares (see Table A3a in the appendix). According to Table 1, the economic growth was not high in Indonesia compared to other ASEAN countries, but it has favored the richest segment of the population disproportionately. While poverty incidence has declined, the growth in this period was not pro-poor in the strict sense (Kakwani and Pernia, 2000; De Silva and Sumarto, 2014). ${ }^{7}$ Like other Asian countries, the urban sector has a much larger expenditure inequality than the rural sector due to the heterogeneous nature of its economy accommodating a wide variety of job opportunities (Eastwood and Lipton, 2004). During the study period, urbanization has proceeded rapidly; in 2000, the urban sector accounted for $42 \%$ of all households, but its share has risen to 50\% in 2011 (see Table 2). Due in part to the rising share of urban households, the level and trends of overall inequality resemble very closely those of urban

\footnotetext{
6 Table A2 in the appendix summarizes these results based on the hierarchical decomposition equation (equation (5)). It also presents the result of a non-hierarchical decomposition analysis (equation (7)).

7 Growth is strictly pro-poor if it is accompanied by the reduction of inequality/
} 
inequality. Meanwhile, expenditure disparity between the urban and rural sectors was not large. After increasing to 0.044 in 2006 from 0.030 in 2000, it has declined to 0.034 in 2011, due in part to declining urban-rural disparity in educational endowments (see Table 5a). The contribution of the between-sector inequality to overall inequality has thus declined to $10.5 \%$ in 2011 from 17.7\% in 2006 (see Tables 5a). ${ }^{8}$ In 2011, 90\% of overall inequality was due to inequalities within the urban and rural sectors.

To further explore the determinants of inequalities within the urban and rural sectors, we conducted a Theil decomposition analysis by educational groups in each sector. According to Table 5a, there is a notable difference between the urban and rural sectors in the contribution of disparity between educational groups. In urban areas, expenditure disparity between educational groups was a prominent contributor to overall inequality, but not in rural areas. Expenditure disparity between educational groups has risen in both urban and rural areas. Particularly, the urban sector increased its between-group disparity notably from 0.035 to 0.076 . The contribution of urban sector's between-group disparity has thus risen from $9.6 \%$ to $14.8 \%$ (see Tables $5 a$ ). In both urban and rural areas, higher educational group tends to have a larger within-group inequality. In 2011, the tertiary education group had the highest within-group inequality at 0.30 in urban areas, which is followed by the secondary and primary education groups, respectively, at 0.24 and 0.23 . The contribution of tertiary group's inequality in urban areas has increased from $11.2 \%$ to $15.6 \%$. In sum, the rise in overall expenditure inequality is due mainly to the rise in disparity between educational groups and tertiary group's inequality in urban areas. Their combined contribution has increased notably from $20.8 \%$ (= 9.6\% + 11.2\%) in 2000 to $30.4 \%(14.8 \%$ $+15.6 \%)$ in 2011.

Since junior secondary education was made compulsory in 1994, secondary education has expanded prominently. According to Figure 1, the GER of secondary education has increased from 55.5\% in 2001 to 79.1\% in 2011. Tertiary education has also expanded very rapidly, with the labor market requiring more formal professional qualifications and demanding a more skilled workforce (Hill and Wie, 2013). According to Figure 2, the GER of tertiary education was $14.2 \%$ in 2001 ; but it increased prominently to $26.3 \%$ in 2011 . The expansion of secondary and tertiary education, particularly in urban areas, appears to have

\footnotetext{
8 The between-sector inequality refers to expenditure disparity between the urban and rural sectors, while the between-group disparity refers to expenditure disparity between educational groups.
} 
played an important role in the rise of overall expenditure inequality by raising not only disparity between educational groups but also inequalities within the tertiary education group.

Based on the 2011 Susenas, Table 6 presents the distribution of households according to occupation in each of the three educational groups. In the tertiary education group, about 8.5\% of urban households are engaged in the information/communication and finance/real estate sectors. This share is much larger than the shares in the primary and secondary education groups ( $0.3 \%$ and $2.4 \%$, respectively). These two sectors have been growing very rapidly; their annual average GDP growth rates, respectively, at $21.1 \%$ and $6.7 \%$ over the period 2000-2011, are much larger than the country's growth rate of 5.3\%. Though not as rapid as the information/communication and finance/real estate sectors, the education, health and government services sectors have also grown more rapidly than the country as a whole, and these services sectors have very large shares in the tertiary education group as compared to the primary and secondary groups. Due to growing demands for technical, managerial and professional skills required for these services sectors, households in the sectors seem to have had increasingly high wages and salaries as they have much higher mean per capita expenditures than those in other sectors in 2011. These observations are indicative of the growing inequality within the tertiary education group.

\section{Table 6}

The tertiary education group comprises three subgroups of households with respect to educational attainment levels: one, two or three-year junior college (subgroup1: Diploma 1, 2 or 3); four-year university/college (subgroup 2: Sarjana 1/Diploma 4); and master's or doctoral program (subgroup 3: Sarjana 2 or 3). Thus, we can further decompose its withingroup inequality into inequalities within and between these three subgroups. Table 7 presents the result of this inequality decomposition in urban areas for 2000 and 2011 . One of the major findings is that variations in mean per capita expenditure among the three subgroups are extremely small in urban areas. In 2011, the ratio between subgroups 1 and 3 in mean per capita expenditure was 1.5, while the ratio between subgroups 1 and 2 was 1.1. This implies that tertiary group's inequality in urban areas is due largely to inequalities within its subgroups. Particularly in 2011, subgroup 1 (Diploma 1, 2 or 3) had a large inequality at 0.40 , a significant increase from 0.23 in 2000 . This seems to have contributed to the rise of expenditure inequality within the tertiary education group. Large inequalities within educational subgroups indicate that there are wide variations in the quality of education at the same education level. 


\section{Table 7}

\subsubsection{Myanmar}

In Myanmar, overall expenditure inequality was 0.40 in 2006, but increased notably to 0.52 in 2012 (see Table 5b). Among Asian countries, this level of expenditure inequality is extremely high (Eastwood and Lipton, 2004). According to the expenditure shares of decile groups, the richest decile group has raised its expenditure share significantly from $35.2 \%$ in 2006 to 38.6\% in 2012, while most other decile groups lost their shares (see Table A3b in the appendix). This indicates that rapid economic growth in this period has favored the richest segment of the population disproportionately, though it has lowered the incidence of poverty (see Table 1). The economic growth in this period (at more than 10\%) was not propoor in the strict sense (Kakwani and Pernia, 2000). Since the urban sector offers a wide variety of job opportunities, urban inequality was much larger than rural inequality (see Table 5b). Both urban and rural inequalities have remained at a high level and have risen significantly. In both urban and rural sectors, only the richest group gained its expenditure shares, suggesting that high economic growth in this period has favored the richest segment of the population in both sectors (see Table A3b).

Expenditure disparity between the urban and rural sectors was not large, though showing an increasing trend; by the Theil index $T$, it accounted for only $1.6 \%$ and $5.3 \%$ of overall expenditure inequality, respectively, in 2006 and 2012 (see Tables 5b). In other words, within-sector inequalities are mostly responsible for high overall expenditure inequality; thus, it is necessary to explore the factors of expenditure inequality within the urban and rural sectors. However, unlike many other Asian countries, where income or expenditure disparity between educational groups accounts for around 15-20\% of overall inequality, expenditure disparity between five educational groups was very small in both urban and rural sectors by accounting, respectively, for $2-3 \%$ and $1-2 \%$ of overall expenditure inequality. As shown in Table A2b in the appendix, the within-sector between-group inequality component (WSBG) accounted for 4.7\% of overall expenditure inequality in 2012 (= 3.2\% in urban + $1.5 \%$ in rural). The combined contribution of the between-sector inequality component (BS) and the within-sector between-group inequality component (WSBG) was $10.0 \%(=5.3 \%+$ 4.7\%) in 2012 (see Table A2b). In other words, 90\% of overall expenditure inequality was due to the within-sector within-group inequality component (WSWG), where WSWG is the weighted average of expenditure inequalities within educational groups in the urban and rural sectors. 
In the urban sector, the tertiary education group had the highest within-group expenditure inequality in 2012 at 0.71 and this was followed by primary at 0.54 and secondary at 0.50 . They together accounted for $38.4 \%$ of overall expenditure inequality (= $10.9 \%+15.3 \%+12.2 \%)$. On the other hand, in the rural sector, the combined contribution of expenditure inequalities within the pre-primary and primary educational groups to overall inequality was $30.9 \%(=20.2 \%+10.7 \%)$. These observations suggest that to alleviate overall expenditure inequality, inequalities within these educational groups need to be reduced.

To further explore the determinants of expenditure inequality, a decomposition analysis by age groups, gender and employment status is conducted in each of these educational groups. However, these household attributes are found to be insignificant in determining expenditure inequality in both urban and rural sectors. It should be noted that in the urban primary and secondary education groups, expenditure inequality increases as we move from younger to older age groups (see Table 8). In the urban tertiary educational group, no such tendency exists; but the oldest group (aged 61 and more) had the highest withingroup inequality. These observations suggest that in urban areas, formal job opportunities are limited for older households and many of these households are likely to be unemployed or work in the informal sector. ${ }^{9}$ In Myanmar, pension coverage is also very low, mainly because only civil servants and political and defense personnel receive pensions at present; thus, retired households in the private sector need to rely on their savings and/or children for livings. In the rural pre-primary and primary education groups, the 51-60 age group had the highest expenditure inequality, and this is followed by the oldest group. The 51-60 age group accounted for one third of expenditure inequality in the rural pre-primary and primary groups. One of the reasons why expenditure inequality is high among older households in rural areas would be that land assets are not distributed equitably, and older landless households are less likely to be employed as laborers in agriculture.

\section{Table 8}

\subsubsection{The Philippines}

In the Philippines, unlike Indonesia and Myanmar, overall expenditure inequality has declined notably from 0.44 to 0.39 over the study period (see Table 5c). But this level of expenditure inequality is still high among Asian countries (Eastwood and Lipton, 2004).

\footnotetext{
9 According to the World Development Indicators, informal employment as a proportion of total nonagricultural employment was high at 83\% in 2015.
} 
According to the expenditure shares of decile groups, the richest decile group has lowered its expenditure share slightly from $36.5 \%$ in 2000 to $35.1 \%$ in 2006, while the other decile groups raised their shares (see Table A3c in the appendix). According to Table 1, the country grew at around $4.5 \%$ in the study period. While the growth was not high among ASEAN countries, it was highly pro-poor (Kakwani and Pernia, 2000). ${ }^{10}$ Like other Asian countries, urban expenditure inequality has been much larger than rural inequality since the urban sector offers a wide variety of job opportunities (Eastwood and Lipton, 2004). During the study period, urban inequality has declined prominently from 0.40 to 0.34 , while rural inequality has risen slightly from 0.27 to 0.28 . On the other hand, expenditure disparity between the urban and rural sectors has fallen from 0.076 to 0.068 . However, the contribution of the between-sector expenditure inequality has remained constant at around $17 \%$ of overall inequality. In other words, more than $80 \%$ of overall inequality was due to inequalities within urban and rural areas.

To explore the determinants of inequalities within the urban and rural sectors, we conduct a Theil decomposition analysis by educational groups in each sector. Like Indonesia and Myanmar, there is a notable difference between the urban and rural sectors in the contribution of disparity between educational groups to overall expenditure inequality. In urban areas, expenditure disparity between educational groups was a prominent contributor to overall inequality; but its contribution has decreased from $15.4 \%$ to $13.1 \%$ (see Table 5c). Unlike Indonesia and Myanmar, however, the contribution of the between-group expenditure inequality in rural areas was not negligible and has increased from $3.7 \%$ to $5.2 \%$. The contribution of the within-sector between-group expenditure inequality (WSBG) has remained almost constant at around 18-19\% (see Tables 5c and Table A2c). In both urban and rural areas, higher educational group tends to have a larger within-group inequality. In 2006, the tertiary education group had the highest within-group inequality at 0.29 in urban areas, which is followed by the secondary and primary education groups, respectively, at 0.25 and 0.23 . In rural areas, the tertiary group also had the highest within-group inequality at 0.28 , which is followed by the secondary and primary education groups.

In urban areas, inequality in the tertiary education group has declined substantially from 0.38 to 0.29 ; thus, its contribution to overall inequality has decreased from $31.2 \%$ to 25.8\% (see Table 5c). We should note that in the Philippines, tertiary education’s GER was

10 Economic growth is highly pro-poor if the growth is accompanied by the fall of inequality. 
relatively high at around $28-30 \%$ during the study period (see Figure 2). The tertiary education group thus accounted for one third of urban households (see Table 2). From these observations, the substantial reduction of overall expenditure inequality appears to have been due to decrease in inequality among urban households with tertiary education. On the other hand, inequality in the secondary education group has risen from 0.21 to 0.25 ; thus, its contribution to overall inequality has increased from $9.5 \%$ to $13.9 \%$. Since expenditure inequalities among urban households with secondary and tertiary education play an important role in determining overall expenditure inequality, we further explore the determinants of these within-group inequalities by conducting an inequality decomposition analysis by age groups, gender and marital status. However, these household attributes are not significant in determining the inequalities. We should note that in urban sector's secondary education group, inequality among female headed households has increased notably from 0.24 to 0.32 by the Theil index $T$. Though female headed households accounted for $22 \%$ of urban households, this appears to have raised inequality among urban households with secondary education. In urban areas, around $60 \%$ of female household heads are either widowed or divorced, which was much larger than that of male household heads (4\%). Female household heads are also much older than male heads. Female headed households with lower education are thus more vulnerable to economic shocks.

\section{Conclusion}

Using data from nation-wide household surveys, this study investigated the roles of education in expenditure inequality in the following three ASEAN countries: Indonesia, Myanmar, and the Philippines. Since disparity between urban and rural areas is one of the main determinants of expenditure inequality and there is a large difference in the socioeconomic structure between urban and rural areas, an analysis was made in an urbanrural framework.

In all three countries, education plays an important role in determining expenditure disparity between the urban and rural sectors since urban-rural difference in educational endowments accounted for around $30-40 \%$ of the difference in mean per capita expenditure. Thus, narrowing urban-rural educational gap is the key to the reduction of expenditure disparity between the urban and rural sectors. In Myanmar, about half of rural households have not completed primary education. This is true even for younger age groups, though primary education has been compulsory. Furthermore, due to insufficient government funding, schools are in poor condition, salaries for teachers are unattractive, and teachers 
need to manage large classes (Hayden and Martin, 2013). Therefore, it is essential to strengthen primary education in rural areas to narrow the urban-rural educational gap. However, unlike Indonesia and the Philippines, the contribution of urban-rural expenditure disparity to overall expenditure inequality was not large. Additionally, in both urban and rural areas, the contribution of expenditure disparity between educational groups was not large either. Therefore, to alleviate overall expenditure inequality, inequalities within educational groups need to be reduced. In urban areas, expansion of secondary education is important given the nature of skills and knowledge required by urban sector jobs. On the other hand, formal job opportunities are limited for older households and many of these households are likely to be unemployed or work in the informal sector. Since older age groups tend to have larger expenditure inequalities in urban areas, the government needs to strengthen social safety net programs and raise pension coverage in the private sector.

In Indonesia and the Philippines, urban-rural expenditure disparity accounted, respectively, for $11 \%$ and $17 \%$ of overall expenditure inequality; thus, narrowing urban-rural educational gap could mitigate overall expenditure inequality by reducing expenditure disparity between the urban and rural sectors. Since a large proportion of rural households had only primary education or less even though primary and secondary education has been compulsory for many years, to reduce urban-rural educational gap, the government needs to improve the quality of primary education and reduce dropout rates at the primary level in rural areas.

In Indonesia and the Philippines, expenditure disparity between educational groups was large in urban areas by accounting for more than $10 \%$ of overall expenditure inequality. It is thus important to reduce expenditure disparity between educational groups in these two countrries. To reduce the educational disparity in urban areas, the government needs to further improve the quality of primary and secondary education and reduce dropout rates at these education levels, thereby raising the enrollment ratio of tertiary education. But, at the same time, the government needs to introduce policies that could reduce variations in quality among tertiary education institutions, since expenditure inequality among urban households with tertiary education was high compared to those with primary and secondary education. Since there seems to have been mismatches between the qualifications of university and college graduates and the needs of employers, the government should also introduce policies that could promote linkages between industry and academia to remove the mismatch. We should note that unlike Indonesia and Myanmar, in the Philippines, the rural sector had a 
relatively high expenditure disparity between educational groups. Particularly, the ratio of the tertiary to primary and secondary education groups in mean per capita expenditure was high. Thus, in rural Philippines, improving the quality of education and reducing dropout rate are important not only at the primary but also secondary education level.

\section{References}

Abdullah, A., Doucouliagos, H., \& Manning, E. (2015). Does education reduce income inequality? A meta-regression analysis. Journal of Economic Surveys, 29(2), 301-316.

Akita, T. (2003). Decomposing regional income inequality in China and Indonesia using two-stage nested Theil decomposition method. The Annals of Regional Science, 37(1), 55-77.

Akita, T., \& Lukman, R.A. (1999). Spatial patterns of expenditure inequalities in Indonesia: 1987, 1990, and 1993. Bulletin of Indonesian Economic Studies, 35, 67-90.

Akita, T., Lukman, R. A., \& Yamada, Y. (1999). Inequality in the distribution of household expenditures in Indonesia: a Theil decomposition analysis. The Developing Economies, 37 (2), 197-221.

Akita, T., \& Miyata, S. (2008). Urbanization, educational expansion, and expenditure inequality in Indonesia in 1996, 1999, and 2002. Journal of the Asia Pacific Economy, 13(2), 147-67.

Akita, T., \& Miyata, S. (2013). The roles of location and education in the distribution of economic well-being in Indonesia: hierarchical and non-hierarchical inequality decomposition analyses. Letters in Spatial and Resource Sciences, 6(3), 137-150.

Anand, S. (1983). Inequality and Poverty in Malaysia: Measurement and Decomposition. New York: Oxford University Press.

Asra, A. (1989). Inequality trends in Indonesia, 1969-1981: A re-examination. Bulletin of Indonesian Economic Studies, 25(2), 100-110.

Asra, A. (2000). Poverty and inequality in Indonesia: estimates, decomposition and key issues. Journal of the Asia and Pacific Economy, 5, 91-111.

Balisacan, A. M., \& Fuwa, N. (2003). Growth, inequality and politics revisited: a developing-country case. Economics Letters 79(1), 53-58.

Balisacan, A. M., \& Fuwa, N. (2004). Changes in spatial income inequality in the Philippines: an exploratory analysis. Research Paper 2004/34, WIDER, United Nations University.

Balisacan, A. M., \& Pernia, E. M. (2002). Probing beneath cross-national averages: poverty, inequality, and growth in the Philippines. ERD Working Paper Series No. 7, Asian Development Bank.

Blinder, A.S. (1973). Wage discrimination: Reduced form and structural estimates. Journal of Human Resources, 8(4), 436-55. 
Bourguignon, F. (1979). Decomposable income inequality measures. Econometrica, 47(4), 901-20.

Ching, P. (1991). Size distribution of income in the Philippines. In T. Mizoguchi (Ed.) Making Economies More Efficient and More Equitable: Factors Determining Income Distribution, Tokyo: Kinokuniya Company, 157-178.

Chongvilaivan, A., \& Kim, J. (2016). Individual income inequality and its drivers in Indonesia: a Theil decomposition reassessment. Social Indicators Research, 126, 79-98.

Chu, H. Y. (2000). The impacts of educational expansion and schooling inequality on income distribution. Quarterly Journal of Business and Economics, 39(2), 39-49.

Dagum, C. (1997). A new approach to the decomposition of the Gini income inequality ratio. Empirical Economics, 22, 515-531.

De Gregorio, J. D, \& Lee, J-W. (2002). Education and income inequality: New evidence form cross-country data. Review of Income and Wealth. vol. 48, pp. 395-416.

De Janvry, A., \& Sadoulet, A. E. (2016). Development Economics: Theory and Practice. New York: Routledge.

De Silva, I., \& Sumarto, S. (2014). Does economic growth really benefit the poor? Income distribution dynamics and pro-poor growth in Indonesia. Bulletin of Indonesian Economic Studies, 50(2), 227-242.

Di Gropello, E. (2011a). Skills for the Labor Market in Indonesia. World Bank. Washington, DC.

Di Gropello, E. (2011b). Skills for the Labor Market in the Philippines. World Bank. Washington, DC.

Dickey, H. (2001). Regional earnings inequality in Great Britain: a decomposition analysis. Regional Studies, 35(7), 605-612.

Eastwood, R. \& Lipton, M. (2004). Rural and urban income inequality and poverty: Does convergence between sectors offset divergence within them? In G. A. Cornia (Ed.) Inequality, Growth, and Poverty in an Era of Liberalization and Globalization. Oxford: Oxford University Press, 112-141.

Estudillo, J.P. (1997). Income inequality in the Philippines, 1961-91. The Developing Economies, 35(1), 68-95.

Glewwe, P. (1986). The distribution of income in Sri Lanka in 1969-70 and 1980-81: A decomposition analysis. Journal of Development Economics, 24(2), 255-274.

Gray, D., Mills, J.A. \& Zandvakili, S. (2003). Statistical analysis of inequality with decompositions: the Canadian experience. Empirical Economics, 28, 291-302.

Haughton, J., \& Khandker, S. R. (2009). Handbook on Poverty and Inequality. Washington, DC: World Bank.

Hayashi, M., Kataoka, M., \& Akita, T. (2014). Expenditure inequality in Indonesia, 20082010: A spatial decomposition analysis and the role of education. Asian Economic Journal, 28(4), 389-411. 
Hayden, M., \& Martin, R. (2013). Recovery of the Education System in Myanmar. Journal of International and Comparative Education, 2013, 2(2), 47-57.

Hill, H., \& Wie, T. K. (2013). Indonesian universities: Rapid growth, major challenges. In D. Suryadarma \& G. W. Jones (Eds.), Education in Indonesia. Singapore: ISEAS Publishing, 160-179.

Hughes, G. A., \& Islam, I. (1981). Inequality in Indonesia: a decomposition analysis. Bulletin of Indonesian Economic Studies, 17(2), 42-71.

Ikemoto, Y., \& Limskul, K. (1987). Income inequality \& regional disparity in Thailand, 1962-81. The Developing Economies, 25(3), 249-269.

Ikemoto, Y. (1985). Income distribution in Malaysia: 1957-80. The Developing Economies, 23(4), 347-67.

Islam, I., \& Khan, H. (1986). Spatial patterns of inequality and poverty in Indonesia. Bulletin of Indonesian Economic Studies, 22(2), 80-102.

Kakwani, N., \& Pernia, E. M. (2000). What is pro-poor growth? Asian Development Review, 18(1), 1-16.

Kanbur, R. \& Zhang , X. (1999) Which Regional Inequality? The evolution of rural-urban and inland-coastal inequality in China from 1983 to 1995. Journal of Comparative Economics, 27, 686-701.

Kanbur, R., \& Zhuang, J. (2013). Urbanization and inequality in Asia. Asian Development Review, 30(1), 131-147.

Knight, J.B., \& Sabot, R.H. (1983). Educational expansion and the Kuznets effect. The American Economic Review, 73(5), 1132-1136.

Lambert, P. J., \& Aronson, J. R. (1993). Inequality decomposition analysis and the Gini coefficient revisited. The Economic Journal, 103, 1221-1227.

Lar, N., Calkins, P., Sriboonchitta, S., \& Leeahtam, P. (2012). Policy-based analysis of the intensity, causes and effects of poverty: the case of Mawlamyine, Myanmar. Canadian Journal of Development Studies, 33(1), 58-76.

Lin, C. H. A. (2006). Educational expansion, educational inequality, and income inequality: Evidence from Taiwan, 1976-2003. Social Indicators Research, 80, 601-615.

Liu, A.Y.C. (2001). Markets, inequality and poverty in Vietnam. Asian Economic Journal, 15(2), 217-235.

Mapa, D. S., Balisacan, A. M., Briones, K. J. S. \& Albis, M. L. F. 2009. What Really Matters for Income Growth in the Philippines: Empirical Evidence from Provincial Data. UPSS Working Paper Series 2009-01, School of Statistics, University of the Philippines, Diliman.

Mesa, E. P. (2007). Measuring education inequality in the Philippines. The Philippine Economic Review, 44(2), 33-70.

Mohanty, S.K., Rasul, G., Mahapatra, B., Choudhury, D., Tuladhar, S., \& Holmgren, E.V. (2018). Multidimensional poverty in mountainous regions: Shan and Chin in Myanmar. 
Social Indicators Research, 138, 23-44.

Motonishi, T. (2006). Why has income inequality in Thailand increased? An analysis using surveys from 1975 to 1998. Japan and the World Economy, 18(4), 464-487.

Mukhopadhaya, P. (2003). Trends in total and subgroup income inequality in the singaporean workforce. Asian Economic Journal, 17(3), 243-264.

Neumark, D. (1988). Employers' discriminatory behavior and the estimation of wage discrimination. Journal of Human Resources, 23(3), 279-95

Oaxaca, R. (1973). Male-female wage differentials in urban labor markets. International Economic Review, 14(3), 693-709.

Park, K. H. (1996). Educational expansion and educational inequality on income distribution. Economics of Education Review, 15(1), 51-58.

Parker, S. C. (1999). The inequality of employment and self-employment incomes: A decomposition analysis for the U.K. Review of Income and Wealth, 45(2), 263-274.

Pernia, E. M. (2008). Migration remittances, poverty and inequality: The Philippines. UPSE Discussion Paper, 2008/01, University of the Philippines, School of Economics.

Ram, R. (1989). Can educational expansion reduce income inequality in less-developed countries. Economics of Education Review, 8(2), 185-195.

Ram, R. (1990). Educational expansion and schooling inequality: international evidence and some implications. The Review of Economics and Statistics, 72(2), 266-274.

Rao, V. V. B., Banerjee, D.S., \& Mukhopadhaya, P. (2003). Earnings inequality in Singapore. Journal of the Asia Pacific Economy, 8(2), 210-228.

Rodrik, D. (2016). Premature deindustrialization. Journal of Economic Growth, 21(1): 1-33.

Seriño, M. N. V. (2014). Decomposition analysis of income inequality in Eastern Visayas, Philippines. DLSU Business \& Economics Review, 24(1), 126-139.

Shaffer, P. (2015). Examining a 'micro-Macro paradox': Did poverty really fall in the Union of Myanmar. Journal of International Development, 27, 1332-1336.

Shorrocks, A. (1980). The class of additively decomposable inequality measures. Econometrica, 48(3), 613-25.

Shorrocks, A., \& Wan, G. (2005). Spatial decomposition of inequality. Journal of Economic Geography. 5(1), 59-81.

Son, H. H. (2008). The role of labor market in explaining growth and inequality in income: the Philippines' case. The Philippines Review of Economics, 45(1), 69-92.

Tang, K.K., \& Petrie, D. (2009). Non-hierarchical bivariate decomposition of Theil indexes. Economics Bulletin, 29(2), 928-927.

Teerawichitchainan, B., and Knodel, J. (2015). Economic status and old-age health in poverty-stricken Myanmar. Journal of Aging and Health, 27(8), 1462 -1484.

Tsakloglou, P. (1993). Aspects of inequality in Greece: measurement, decomposition and 
intertemporal change, 1974, 1982. Journal of Development Economics, 40(1), 5374.UNESCO (2011). World Data on Education. UNESCO, Paris, France.

UNESCO (2011). Philippine Education for All 2015 Review Report. UNESCO, Paris, France.

Wagle, U. (2016), The role of remittances in determining economic security and poverty in Myanmar. The European Journal of Development Research, 28(4), 536-554.

World Bank. (2017). An Analysis of Poverty in Myanmar, Part 2. Washington, D.C: World Bank. 
Table 1. GDP and Manufacturing Value Added at Constant 2010 US Dollars

\begin{tabular}{|c|c|c|c|c|c|c|c|}
\hline & \multicolumn{4}{|c|}{ GDP, population, and manufacturing value added } & \multicolumn{3}{|c|}{ Growth rate (\%) } \\
\hline & 2000 & 2005 & 2010 & 2015 & $00-05$ & $05-10$ & $10-15$ \\
\hline \multicolumn{8}{|c|}{ GDP (million US dollars) } \\
\hline Indonesia & 453,414 & 571,205 & 755,094 & 988,129 & 4.6 & 5.6 & 5.4 \\
\hline Myanmar & 15,985 & 29,275 & 49,541 & 70,340 & 12.1 & 10.5 & 7.0 \\
\hline Philippines & 125,348 & 156,874 & 199,591 & 266,055 & 4.5 & 4.8 & 5.7 \\
\hline ASEAN & $1,181,299$ & $1,517,081$ & $1,974,459$ & $2,528,391$ & 5.0 & 5.3 & 4.9 \\
\hline \multicolumn{8}{|c|}{ Population (thousand) } \\
\hline Indonesia & 211,514 & 226,289 & 241,834 & 258,383 & 1.4 & 1.3 & 1.3 \\
\hline Myanmar & 46,720 & 48,950 & 50,601 & 52,681 & 0.9 & 0.7 & 0.8 \\
\hline Philippines & 77,992 & 86,326 & 93,967 & 102,113 & 2.0 & 1.7 & 1.7 \\
\hline ASEAN & 523,789 & 559,796 & 595,411 & 632,637 & 1.3 & 1.2 & 1.2 \\
\hline \multicolumn{8}{|c|}{ Per capita GDP (US dollars) } \\
\hline Indonesia & 2,144 & 2,524 & 3,122 & 3,824 & 3.3 & 4.3 & 4.1 \\
\hline Myanmar & 342 & 598 & 979 & 1,335 & 11.2 & 9.9 & 6.2 \\
\hline Philippines & 1,607 & 1,817 & 2,124 & 2,605 & 2.5 & 3.1 & 4.1 \\
\hline ASEAN & 2,255 & 2,710 & 3,316 & 3,997 & 3.7 & 4.0 & 3.7 \\
\hline \multicolumn{8}{|c|}{ Manufacturing value added (million US dollars) } \\
\hline Indonesia & 107,460 & 136,991 & 166,412 & 212,810 & 4.9 & 3.9 & 4.9 \\
\hline Myanmar & 1,145 & 3,332 & 9,840 & 15,564 & 21.4 & 21.7 & 9.2 \\
\hline Philippines & 29,655 & 35,968 & 42,802 & 59,606 & 3.9 & 3.5 & 6.6 \\
\hline ASEAN & 279,450 & 364,035 & 452,070 & 556,238 & 5.3 & 4.3 & 4.1 \\
\hline \multicolumn{8}{|c|}{ Ratio of manufacturing value added to total GDP (\%) } \\
\hline Indonesia & 23.7 & 24.0 & 22.0 & 21.5 & & & \\
\hline Myanmar & 7.2 & 11.4 & 19.9 & 22.1 & & & \\
\hline Philippines & 23.7 & 22.9 & 21.4 & 22.4 & & & \\
\hline ASEAN & 23.7 & 24.0 & 22.9 & 22.0 & & & \\
\hline
\end{tabular}

(Note) ASEAN excludes Brunei.

(Source) Authors' calculation from World Development Indicators, World Bank 
Table 2. Household Surveys in Indonesia, Myanmar and the Philippines

\begin{tabular}{|c|c|c|c|c|c|c|}
\hline \multirow{2}{*}{ Indonesia } & \multicolumn{3}{|c|}{ Sample size } & \multicolumn{3}{|c|}{ Distribution of households (\%) } \\
\hline & Urban & Rural & Total & Urban & Rural & Total \\
\hline \multicolumn{7}{|l|}{2000} \\
\hline Primary & 32,053 & 87,015 & 119,068 & 45 & 78 & 64 \\
\hline Secondary & 33,708 & 25,879 & 59,587 & 44 & 20 & 30 \\
\hline Tertiary & 8,168 & 2,500 & 10,668 & 11 & 2 & 5 \\
\hline Total & 73,929 & 115,394 & 189,323 & 100 & 100 & 100 \\
\hline Urban \& rural shares & & & & 42 & 58 & 100 \\
\hline \multicolumn{7}{|l|}{2006} \\
\hline Primary & 38,072 & 113,461 & 151,533 & 41 & 73 & 59 \\
\hline Secondary & 47,973 & 47,047 & 95,020 & 47 & 24 & 34 \\
\hline Tertiary & 12,193 & 4,718 & 16,911 & 12 & 3 & 7 \\
\hline Total & 98,238 & 165,226 & 263,464 & 100 & 100 & 100 \\
\hline Urban \& rural shares & & & & 43 & 57 & 100 \\
\hline \multicolumn{7}{|l|}{2011} \\
\hline Primary & 43,304 & 102,758 & 146,062 & 40 & 69 & 54 \\
\hline Secondary & 53,520 & 46,127 & 99,647 & 47 & 28 & 37 \\
\hline Tertiary & 16,573 & 6,240 & 22,813 & 13 & 3 & 8 \\
\hline Total & 113,397 & 155,125 & 268,522 & 100 & 100 & 100 \\
\hline Urban \& rural shares & & & & 50 & 50 & 100 \\
\hline \multirow{2}{*}{ Myanmar } & \multicolumn{3}{|c|}{ Sample size } & \multicolumn{3}{|c|}{ Distribution of households (\%) } \\
\hline & Urban & Rural & Total & Urban & Rural & Total \\
\hline \multicolumn{7}{|l|}{2006} \\
\hline No education & 561 & 982 & 1,543 & 3 & 6 & 5 \\
\hline Pre-primary & 4,810 & 6,387 & 11,197 & 26 & 44 & 38 \\
\hline Primary & 4,129 & 4,078 & 8,207 & 24 & 28 & 26 \\
\hline Secondary & 6,252 & 2,592 & 8,844 & 37 & 19 & 26 \\
\hline Tertiary & 1,847 & 358 & 2,205 & 11 & 3 & 6 \\
\hline Total & 17,599 & 14,397 & 31,996 & 100 & 100 & 100 \\
\hline Urban \& rural shares & & & & 35 & 65 & 100 \\
\hline \multicolumn{7}{|l|}{2012} \\
\hline No education & 506 & 637 & 1,143 & 2 & 4 & 3 \\
\hline Pre-primary & 5,416 & 7,077 & 12,493 & 28 & 48 & 41 \\
\hline Primary & 4,411 & 4,464 & 8,875 & 26 & 32 & 30 \\
\hline Secondary & 5,557 & 1,881 & 7,438 & 32 & 14 & 20 \\
\hline Tertiary & 2,258 & 288 & 2,546 & 12 & 2 & 5 \\
\hline Total & 18,148 & 14,347 & 32,495 & 100 & 100 & 100 \\
\hline Urban \& rural shares & & & & 34 & 66 & 100 \\
\hline \multirow{2}{*}{ Philippines } & \multicolumn{3}{|c|}{ Sample size } & \multicolumn{3}{|c|}{ Distribution of households (\%) } \\
\hline & Urban & Rural & Total & Urban & Rural & Total \\
\hline \multicolumn{7}{|l|}{2000} \\
\hline Primary & 7,905 & 10,022 & 17,927 & 32 & 63 & 47 \\
\hline Secondary & 8,398 & 4,298 & 12,696 & 37 & 27 & 32 \\
\hline Tertiary & 7,221 & 1,771 & 8,992 & 32 & 11 & 21 \\
\hline Total & 23,524 & 16,091 & 39,615 & 100 & 100 & 100 \\
\hline Urban \& rural shares & & & & 49 & 51 & 100 \\
\hline \multicolumn{7}{|l|}{2006} \\
\hline Primary & 4,988 & 12,484 & 17,472 & 28 & 59 & 44 \\
\hline Secondary & 6,633 & 6,109 & 12,742 & 39 & 29 & 34 \\
\hline Tertiary & 5,644 & 2,621 & 8,265 & 33 & 12 & 22 \\
\hline Total & 17,265 & 21,214 & 38,479 & 100 & 100 & 100 \\
\hline Urban \& rural shares & & & & 50 & 50 & 100 \\
\hline
\end{tabular}

(Notes) The distribution of households is estimated using sampling household weights.

(Sources) Susenas in 2000, 2006 and 2011 for Indonesia, HIES in 2006 and 2012 for Myanmar, and FIES in 2000 and 2006 for the Philippines. 
Table 3a. Decomposition of Educational Gini by Location (Urban and Rural Sectors), Indonesia

\begin{tabular}{|c|c|c|c|c|c|}
\hline & $\begin{array}{r}\text { Gini } \\
\text { index }\end{array}$ & $\begin{array}{r}\text { Absolute } \\
\text { contribution }\end{array}$ & $\begin{array}{r}\text { Relative } \\
\text { contribution } \\
(\%) \\
\end{array}$ & $\begin{array}{r}\text { Population } \\
\text { share } \\
(\%) \\
\end{array}$ & $\begin{array}{l}\text { Mean years } \\
\text { of education }\end{array}$ \\
\hline \multicolumn{6}{|l|}{2000} \\
\hline Urban sector (1) & 0.297 & 0.068 & 18.3 & 42.2 & 8.3 \\
\hline Rural sector (2) & 0.393 & 0.104 & 28.0 & 57.8 & 5.1 \\
\hline Within-sector $(3)=(1)+(2)$ & & 0.172 & 46.4 & & \\
\hline Between-sector (4) & & 0.120 & 32.4 & & \\
\hline Urban \& rural overlap (5) & & 0.079 & 21.2 & & \\
\hline Total $(6)=(3)+(4)+(5)$ & 0.371 & 0.371 & 100.0 & 100.0 & 6.5 \\
\hline \multicolumn{6}{|l|}{2006} \\
\hline Urban sector (1) & 0.279 & 0.065 & 19.2 & 43.3 & 8.8 \\
\hline Rural sector (2) & 0.355 & 0.093 & 27.3 & 56.7 & 5.7 \\
\hline Within-sector $(3)=(1)+(2)$ & & 0.158 & 46.5 & & \\
\hline Between-sector (4) & & 0.106 & 31.1 & & \\
\hline Urban \& rural overlap (5) & & 0.076 & 22.4 & & \\
\hline Total $(6)=(3)+(4)+(5)$ & 0.340 & 0.340 & 100.0 & 100.0 & 7.1 \\
\hline \multicolumn{6}{|l|}{2011} \\
\hline Urban sector (1) & 0.291 & 0.086 & 26.0 & 49.9 & 9.2 \\
\hline Rural sector (2) & 0.339 & 0.069 & 21.0 & 50.1 & 6.3 \\
\hline Within-sector $(3)=(1)+(2)$ & & 0.155 & 47.0 & & \\
\hline Between-sector (4) & & 0.093 & 28.2 & & \\
\hline Urban \& rural overlap (5) & & 0.082 & 24.8 & & \\
\hline Total $(6)=(3)+(4)+(5)$ & 0.330 & 0.330 & 100.0 & 100.0 & 7.7 \\
\hline
\end{tabular}

(Source) Authors’ calculation from Susenas in 2000, 2006 and 2011.

Table 3b. Decomposition of Educational Gini by Location (Urban and Rural Sectors), Myanmar

\begin{tabular}{|c|c|c|c|c|c|}
\hline & $\begin{array}{l}\text { Gini } \\
\text { index }\end{array}$ & $\begin{array}{r}\text { Absolute } \\
\text { contribution }\end{array}$ & $\begin{array}{r}\text { Relative } \\
\text { contribution } \\
(\%)\end{array}$ & $\begin{array}{r}\text { Population } \\
\text { share } \\
(\%)\end{array}$ & $\begin{array}{l}\text { Mean years } \\
\text { of education }\end{array}$ \\
\hline \multicolumn{6}{|l|}{2006} \\
\hline Urban sector (1) & 0.313 & 0.047 & 13.5 & 34.9 & 7.0 \\
\hline Rural sector (2) & 0.349 & 0.129 & 36.7 & 65.1 & 4.9 \\
\hline Within-sector $(3)=(1)+(2)$ & & 0.176 & 50.3 & & \\
\hline Between-sector (4) & & 0.086 & 24.6 & & \\
\hline Urban \& rural overlap (5) & & 0.088 & 25.2 & & \\
\hline Total $(6)=(3)+(4)+(5)$ & 0.350 & 0.350 & 100.0 & 100.0 & 5.6 \\
\hline \multicolumn{6}{|l|}{2012} \\
\hline Urban sector (1) & 0.310 & 0.046 & 14.1 & 34.0 & 6.9 \\
\hline Rural sector (2) & 0.299 & 0.112 & 34.7 & 66.0 & 4.7 \\
\hline Within-sector $(3)=(1)+(2)$ & & 0.158 & 48.8 & & \\
\hline Between-sector (4) & & 0.091 & 28.2 & & \\
\hline Urban \& rural overlap (5) & & 0.074 & 23.0 & & \\
\hline Total $(6)=(3)+(4)+(5)$ & 0.323 & 0.323 & 100.0 & 100.0 & 5.4 \\
\hline
\end{tabular}

(Source) Authors’ calculation from HIES in 2006 and 2012. 
Table 3c. Decomposition of Educational Gini by Location (Urban and Rural Sectors), Philippines

\begin{tabular}{|c|c|c|c|c|c|}
\hline & $\begin{array}{r}\text { Gini } \\
\text { index }\end{array}$ & $\begin{array}{r}\text { Absolute } \\
\text { contribution }\end{array}$ & $\begin{array}{r}\text { Relative } \\
\text { contribution } \\
(\%) \\
\end{array}$ & $\begin{array}{r}\text { Population } \\
\text { share } \\
(\%)\end{array}$ & $\begin{array}{r}\text { Mean years of } \\
\text { education }\end{array}$ \\
\hline \multicolumn{6}{|l|}{2000} \\
\hline Urban sector (1) & 0.232 & 0.067 & 23 & 49 & 9.0 \\
\hline Rural sector (2) & 0.320 & 0.068 & 23 & 51 & 6.3 \\
\hline Within-sector $(3)=(1)+(2)$ & & 0.134 & 46 & & \\
\hline Between-sector (4) & & 0.089 & 31 & & \\
\hline Urban \& rural overlap (5) & & 0.067 & 23 & & \\
\hline Total $(6)=(3)+(4)+(5)$ & 0.290 & 0.290 & 100 & 100 & 7.6 \\
\hline \multicolumn{6}{|l|}{2006} \\
\hline Urban sector (1) & 0.218 & 0.063 & 23 & 50 & 9.2 \\
\hline Rural sector (2) & 0.308 & 0.065 & 24 & 50 & 6.6 \\
\hline Within-sector $(3)=(1)+(2)$ & & 0.128 & 46 & & \\
\hline Between-sector (4) & & 0.083 & 30 & & \\
\hline Urban \& rural overlap (5) & & 0.065 & 24 & & \\
\hline Total $(6)=(3)+(4)+(5)$ & 0.275 & 0.275 & 100 & 100 & 7.8 \\
\hline
\end{tabular}

(Source) Authors' calculation from FIES in 2000 and 2006. 
Table 4a. Blinder-Oaxaca Decomposition of Urban-Rural Difference in Mean Per Capita Expenditure, Indonesia

\begin{tabular}{|c|c|c|c|c|c|c|}
\hline & \multicolumn{3}{|c|}{2000} & \multicolumn{3}{|c|}{2006} \\
\hline & Coefficient & $\mathrm{z}$ value & $\begin{array}{r}\text { Contribution } \\
(\%)\end{array}$ & Coefficient & $\mathrm{z}$ value & $\begin{array}{r}\text { Contribution } \\
\text { (\%) }\end{array}$ \\
\hline \multicolumn{7}{|l|}{ Differential } \\
\hline Prediction for urban & 11.923 & $5,880.5$ & & 12.751 & $6,715.0$ & \\
\hline Prediction for rural & 11.523 & $8,705.5$ & & 12.280 & $10,000.0$ & \\
\hline Difference & 0.400 & 165.4 & 100.0 & 0.472 & 210.7 & 100.0 \\
\hline \multicolumn{7}{|l|}{ Explained part } \\
\hline Years of education & 0.136 & 111.0 & 33.9 & 0.143 & 128.7 & 30.3 \\
\hline Age & -0.006 & -6.3 & -1.5 & -0.012 & -13.0 & -2.5 \\
\hline Age squared & 0.004 & 5.6 & 0.9 & 0.008 & 12.2 & 1.8 \\
\hline Household size & -0.012 & -11.7 & -3.0 & -0.006 & -6.4 & -1.2 \\
\hline Gender & 0.000 & 6.3 & 0.1 & 0.000 & 3.1 & 0.0 \\
\hline Total & 0.122 & 80.3 & 30.5 & 0.134 & 100.7 & 28.4 \\
\hline \multicolumn{7}{|l|}{ Unexplained part } \\
\hline \multirow[t]{3}{*}{ Total } & 0.278 & 127.9 & 69.5 & 0.338 & 169.3 & 71.6 \\
\hline & & 2011 & & & & \\
\hline & Coefficient & $\mathrm{z}$ value & $\begin{array}{r}\text { Contribution } \\
(\%)\end{array}$ & & & \\
\hline \multicolumn{7}{|l|}{$\overline{\text { Differential }}$} \\
\hline Prediction for urban & 13.338 & $6,679.1$ & & & & \\
\hline Prediction for rural & 12.921 & $8,858.1$ & & & & \\
\hline Difference & 0.417 & 168.6 & 100.0 & & & \\
\hline \multicolumn{7}{|l|}{ Explained part } \\
\hline Years of education & 0.176 & 134.8 & 42.3 & & & \\
\hline Age & -0.013 & -13.0 & -3.1 & & & \\
\hline Age squared & 0.010 & 12.7 & 2.5 & & & \\
\hline Household size & 0.004 & 5.1 & 1.0 & & & \\
\hline Gender & 0.000 & 4.3 & 0.0 & & & \\
\hline Total & 0.178 & 122.0 & 42.8 & & & \\
\hline \multicolumn{7}{|l|}{ Unexplained part } \\
\hline Total & 0.239 & 107.6 & 57.2 & & & \\
\hline
\end{tabular}

(Source) Authors' calculation from Susenas in 2000, 2006 and 2011.

Table 4b. Blinder-Oaxaca Decomposition of Urban-Rural Difference in Mean Per Capita Expenditure, Myanmar

\begin{tabular}{|c|c|c|c|c|c|c|}
\hline & \multicolumn{3}{|c|}{2006} & \multicolumn{3}{|c|}{2012} \\
\hline & Coefficient & $\mathrm{z}$ value & $\begin{array}{r}\text { Contribution } \\
(\%) \\
\end{array}$ & Coefficient & $\mathrm{z}$ value & $\begin{array}{r}\text { Contribution } \\
(\%) \\
\end{array}$ \\
\hline \multicolumn{7}{|l|}{ Differential } \\
\hline Prediction for urban & 10.752 & 14,000 & & 11.627 & 13,000 & \\
\hline Prediction for rural & 10.589 & 20,000 & & 11.249 & 20,000 & \\
\hline Difference & 0.163 & 173 & & 0.378 & 357 & \\
\hline \multicolumn{7}{|l|}{ Explained part } \\
\hline Years of education & 0.066 & 208 & 40.6 & 0.114 & 273 & 30.1 \\
\hline Age & 0.008 & 22 & 4.6 & 0.047 & 75 & 12.5 \\
\hline Age squared & -0.005 & -15 & -3.0 & -0.041 & -67 & -10.8 \\
\hline Household size & -0.003 & -13 & -1.8 & 0.005 & 19 & 1.3 \\
\hline Gender & 0.000 & 3 & 0.1 & -0.001 & -12 & -0.3 \\
\hline Unemployment & -0.012 & -84 & -7.2 & 0.000 & 10 & 0.0 \\
\hline Total & 0.054 & 125 & 33.3 & 0.124 & 234 & 32.9 \\
\hline \multicolumn{7}{|l|}{ Unexplained part } \\
\hline Total & 0.109 & 116 & 66.7 & 0.254 & 239 & 67.1 \\
\hline
\end{tabular}

(Source) Authors’ calculation from HIES in 2006 and 2012. 
Table 4c. Blinder-Oaxaca Decomposition of Urban-Rural Difference in Mean Per Capita Expenditure, Philippines

\begin{tabular}{|c|c|c|c|c|c|c|}
\hline & \multicolumn{3}{|c|}{2000} & \multicolumn{3}{|c|}{2006} \\
\hline & Coefficient & $\mathrm{z}$ value & $\begin{array}{r}\text { Contribution } \\
(\%)\end{array}$ & Coefficient & $\mathrm{z}$ value & $\begin{array}{r}\text { Contribution } \\
(\%)\end{array}$ \\
\hline \multicolumn{7}{|l|}{ Differential } \\
\hline Prediction for urban & 10.062 & 2027.4 & & 10.445 & 1803.4 & \\
\hline Prediction for rural & 9.448 & 1893.7 & & 9.768 & 2211.7 & \\
\hline Difference & 0.614 & 87.3 & & 0.676 & 92.9 & \\
\hline \multicolumn{7}{|l|}{ Explained part } \\
\hline Years of education & 0.216 & 55.6 & 35.1 & 0.218 & 56.5 & 32.2 \\
\hline Age & -0.004 & -1.3 & -0.7 & -0.013 & -4.5 & -1.9 \\
\hline Age squared & 0.004 & 1.8 & 0.7 & 0.007 & 4.0 & 1.1 \\
\hline Agriculture & 0.114 & 40.0 & 18.6 & 0.105 & 40.4 & 15.5 \\
\hline Household size & 0.002 & 0.9 & 0.4 & 0.008 & 3.1 & 1.2 \\
\hline Gender & 0.004 & 7.1 & 0.6 & 0.005 & 7.6 & 0.7 \\
\hline Total & 0.336 & 62.7 & 54.7 & 0.329 & 62.3 & 48.7 \\
\hline \multicolumn{7}{|l|}{ Unexplained part } \\
\hline Total & 0.278 & 44.4 & 45.3 & 0.347 & 55.0 & 51.3 \\
\hline
\end{tabular}

(Source) Authors' calculation from FIES in 2000 and 2006. 
Table 5a. Decomposition of Expenditure Inequality by Location and Education, Indonesia

\begin{tabular}{|c|c|c|c|c|c|c|c|}
\hline & Theil T & $\begin{array}{r}\text { Contribution } \\
(\%)\end{array}$ & $\begin{array}{r}\text { Expenditure } \\
\text { share (\%) }\end{array}$ & & Theil T & $\begin{array}{r}\text { Contribution } \\
(\%)\end{array}$ & $\begin{array}{l}\text { Expenditure } \\
\text { share (\%) }\end{array}$ \\
\hline \multicolumn{8}{|l|}{2000} \\
\hline Total $(1)=(2)+(3)$ & 0.200 & 100.0 & 100.0 & & & & \\
\hline B-sector (2) & 0.030 & 14.9 & & & & & \\
\hline W-sector (3) = (a) + (d) & 0.171 & 85.1 & & & & & \\
\hline Urban $(a)=(c)+(d)$ & 0.220 & 59.7 & 54.4 & Rural (d) $=(\mathrm{e})+(\mathrm{f})$ & 0.112 & 25.4 & 45.6 \\
\hline B-group (c) & 0.035 & 9.6 & & B-group (e) & 0.006 & 1.2 & \\
\hline W-group (d) & 0.185 & 50.1 & & W-group (f) & 0.106 & 24.2 & \\
\hline Primary & 0.148 & 14.1 & 19.1 & Primary & 0.101 & 17.1 & 33.9 \\
\hline Secondary & 0.195 & 24.7 & 25.4 & Secondary & 0.117 & 6.1 & 10.4 \\
\hline Tertiary & 0.230 & 11.2 & 9.8 & Tertiary & 0.156 & 1.0 & 1.3 \\
\hline \multicolumn{8}{|l|}{2006} \\
\hline Total $(1)=(2)+(3)$ & 0.248 & 100.0 & 100.0 & & & & \\
\hline B-sector (2) & 0.044 & 17.7 & & & & & \\
\hline W-sector $(3)=(a)+(d)$ & 0.204 & 82.3 & & & & & \\
\hline Urban $(a)=(c)+(d)$ & 0.251 & 58.7 & 58.1 & Rural (d) $=(\mathrm{e})+(\mathrm{f})$ & 0.139 & 23.6 & 41.9 \\
\hline B-group (c) & 0.051 & 11.9 & & B-group (e) & 0.010 & 1.7 & \\
\hline W-group (d) & 0.200 & 46.8 & & W-group (f) & 0.129 & 21.9 & \\
\hline Primary & 0.170 & 11.7 & 17.1 & Primary & 0.115 & 13.3 & 28.6 \\
\hline Secondary & 0.190 & 21.5 & 28.1 & Secondary & 0.154 & 7.2 & 11.6 \\
\hline Tertiary & 0.263 & 13.6 & 12.9 & Tertiary & 0.197 & 1.4 & 1.8 \\
\hline \multicolumn{8}{|l|}{2011} \\
\hline Total $(1)=(2)+(3)$ & 0.322 & 100.0 & 100.0 & & & & \\
\hline B-sector (2) & 0.034 & 10.5 & & & & & \\
\hline $\mathrm{W}$-sector $(3)=(\mathrm{a})+(\mathrm{d})$ & 0.288 & 89.5 & & & & & \\
\hline Urban $(\mathrm{a})=(\mathrm{c})+(\mathrm{d})$ & 0.330 & 64.5 & 62.9 & Rural (d) $=(\mathrm{e})+(\mathrm{f})$ & 0.217 & 25.0 & 37.1 \\
\hline B-group (c) & 0.076 & 14.8 & & B-group (e) & 0.019 & 2.2 & \\
\hline W-group (d) & 0.255 & 49.7 & & W-group (f) & 0.198 & 22.8 & \\
\hline Primary & 0.232 & 11.8 & 16.4 & Primary & 0.183 & 12.9 & 22.6 \\
\hline Secondary & 0.241 & 22.3 & 29.8 & Secondary & 0.216 & 8.2 & 12.2 \\
\hline Tertiary & 0.301 & 15.6 & 16.6 & Tertiary & 0.242 & 1.8 & 2.4 \\
\hline
\end{tabular}

(Source) Authors' calculation from Susenas in 2000, 2006 and 2011.

Table 5b. Decomposition of Expenditure Inequality by Location and Education, Myanmar

\begin{tabular}{|c|c|c|c|c|c|c|c|}
\hline & Theil T & $\begin{array}{r}\text { Contribution } \\
(\%)\end{array}$ & $\begin{array}{l}\text { Expenditure } \\
\text { Share (\%) }\end{array}$ & & Theil T & $\begin{array}{r}\text { Contributio } \\
\mathrm{n} \\
(\%) \\
\end{array}$ & $\begin{array}{l}\text { Expenditure } \\
\text { Share (\%) }\end{array}$ \\
\hline \multicolumn{8}{|l|}{2006} \\
\hline Total $(1)=(2)+(3)$ & 0.400 & 100.0 & & & & & \\
\hline B-sector (2) & 0.006 & 1.6 & & & & & \\
\hline W-sector $(3)=(a)+(d)$ & 0.393 & 98.4 & & & & & \\
\hline Urban (a) = (b) + (c) & 0.468 & 47.0 & 40.2 & Rural $(\mathrm{d})=(\mathrm{e})+(\mathrm{f})$ & 0.344 & 51.4 & 59.8 \\
\hline B-group (b) & 0.026 & 2.6 & & B-group (e) & 0.006 & 1.0 & \\
\hline W-group (c) & 0.442 & 44.4 & & W-group (f) & 0.337 & 50.4 & \\
\hline No education & 0.789 & 1.8 & 0.9 & No education & 0.267 & 1.7 & 2.5 \\
\hline Pre-primary & 0.382 & 7.7 & 8.1 & Pre-primary & 0.354 & 22.3 & 25.2 \\
\hline Primary & 0.326 & 6.8 & 8.3 & Primary & 0.301 & 12.5 & 16.6 \\
\hline Secondary & 0.432 & 17.2 & 16.0 & Secondary & 0.360 & 11.9 & 13.2 \\
\hline Tertiary & 0.630 & 10.9 & 7.0 & Tertiary & 0.361 & 2.0 & 2.2 \\
\hline \multicolumn{8}{|l|}{2012} \\
\hline Total $(1)=(2)+(3)$ & 0.520 & 100.0 & & & & & \\
\hline B-sector (2) & 0.028 & 5.3 & & & & & \\
\hline W-sector (3) $=(\mathrm{a})+(\mathrm{d})$ & 0.492 & 94.7 & & & & & \\
\hline Urban (a) $=(\mathrm{b})+(\mathrm{c})$ & 0.574 & 49.9 & 45.3 & Rural $(\mathrm{d})=(\mathrm{e})+(\mathrm{f})$ & 0.425 & 44.8 & 54.7 \\
\hline B-group (b) & 0.038 & 3.2 & & B-group (e) & 0.013 & 1.5 & \\
\hline W-group (c) & 0.536 & 46.7 & & W-group (f) & 0.412 & 43.3 & \\
\hline No education & 0.339 & 0.4 & 0.6 & No education & 0.928 & 3.4 & 1.9 \\
\hline Pre-primary & 0.446 & 7.9 & 9.2 & Pre-primary & 0.447 & 20.1 & 23.5 \\
\hline Primary & 0.537 & 10.9 & 10.5 & Primary & 0.315 & 10.7 & 17.7 \\
\hline Secondary & 0.498 & 15.3 & 15.9 & Secondary & 0.364 & 6.8 & 9.7 \\
\hline Tertiary & 0.710 & 12.2 & 9.0 & Tertiary & 0.604 & 2.3 & 2.0 \\
\hline
\end{tabular}


(Source) Authors' calculation from HIES in 2006 and 2012. 
Table 5c. Decomposition of Expenditure Inequality by Location and Education, Philippines

\begin{tabular}{|c|c|c|c|c|c|c|c|}
\hline & Theil $\mathrm{T}$ & $\begin{array}{r}\text { Contribution } \\
(\%)\end{array}$ & $\begin{array}{r}\text { Expenditure } \\
\text { share (\%) }\end{array}$ & & Theil $\mathrm{T}$ & $\begin{array}{r}\text { Contribution } \\
(\%)\end{array}$ & $\begin{array}{l}\text { Expenditure } \\
\text { share (\%) }\end{array}$ \\
\hline \multicolumn{8}{|l|}{2000} \\
\hline Total $(1)=(2)+(3)$ & 0.438 & 100.0 & 100.0 & & & & \\
\hline B-sector (2) & 0.076 & 17.3 & & & & & \\
\hline W-sector $(3)=(\mathrm{a})+(\mathrm{d})$ & 0.362 & 82.7 & & & & & \\
\hline Urban $(\mathrm{a})=(\mathrm{c})+(\mathrm{d})$ & 0.404 & 63.4 & 68.7 & Rural (d) $=(\mathrm{e})+(\mathrm{f})$ & 0.270 & 19.3 & 31.3 \\
\hline B-group (c) & 0.098 & 15.4 & & B-group (e) & 0.052 & 3.7 & \\
\hline W-group (d) & 0.306 & 48.0 & & W-group (f) & 0.219 & 15.6 & \\
\hline Primary & 0.244 & 7.2 & 13.0 & Primary & 0.192 & 7.0 & 16.0 \\
\hline Secondary & 0.212 & 9.5 & 19.7 & Secondary & 0.212 & 4.2 & 8.8 \\
\hline Tertiary & 0.380 & 31.2 & 36.0 & Tertiary & 0.292 & 4.4 & 6.6 \\
\hline \multicolumn{8}{|l|}{2006} \\
\hline Total $(1)=(2)+(3)$ & 0.391 & 100.0 & 100.0 & & & & \\
\hline B-sector (2) & 0.068 & 17.4 & & & & & \\
\hline $\mathrm{W}$-sector $(3)=(\mathrm{a})+(\mathrm{d})$ & 0.323 & 82.6 & & & & & \\
\hline Urban $(\mathrm{a})=(\mathrm{c})+(\mathrm{d})$ & 0.343 & 59.5 & 67.8 & Rural (d) $=(\mathrm{e})+(\mathrm{f})$ & 0.281 & 23.1 & 32.2 \\
\hline B-group (c) & 0.076 & 13.1 & & B-group (e) & 0.063 & 5.2 & \\
\hline W-group (d) & 0.267 & 46.4 & & W-group (f) & 0.218 & 17.9 & \\
\hline Primary & 0.227 & 6.7 & 11.5 & Primary & 0.190 & 7.1 & 14.7 \\
\hline Secondary & 0.247 & 13.9 & 22.0 & Secondary & 0.213 & 5.2 & 9.6 \\
\hline Tertiary & 0.294 & 25.8 & 34.3 & Tertiary & 0.278 & 5.6 & 7.8 \\
\hline
\end{tabular}

(Source) Authors' calculation from FIES in 2000 and 2006.

Table 6. Distribution of Households according to Occupations in Each Educational Group in 2011 in Indonesia

\begin{tabular}{|c|c|c|c|c|c|c|c|c|c|c|c|}
\hline & \multicolumn{5}{|c|}{ Urban Sector } & \multicolumn{5}{|c|}{ Rural Sector } & \multirow[b]{2}{*}{$\begin{array}{r}\text { GDP } \\
\text { Growth } \\
\text { Rate } \\
2000-11 \\
(\%)\end{array}$} \\
\hline & $\begin{array}{r}\text { Mean } \\
\text { PCE } \\
(1,000 \\
\text { Rp. })\end{array}$ & $\begin{array}{r}\text { Primary } \\
(\%)\end{array}$ & $\begin{array}{r}\text { Second. } \\
(\%)\end{array}$ & $\begin{array}{r}\text { Tertiary } \\
(\%)\end{array}$ & $\begin{array}{r}\text { Total } \\
(\%)\end{array}$ & $\begin{array}{r}\text { Mean } \\
\text { PCE } \\
(1,000 \\
\text { Rp. })\end{array}$ & $\begin{array}{r}\text { Primary } \\
(\%)\end{array}$ & $\begin{array}{r}\text { Second. } \\
(\%)\end{array}$ & $\begin{array}{r}\text { Tertiary } \\
(\%)\end{array}$ & $\begin{array}{r}\text { Total } \\
(\%)\end{array}$ & \\
\hline Agriculture & 476 & 28.3 & 7.5 & 3.1 & 14.8 & 421 & 67.5 & 47.3 & 13.5 & 59.7 & 3.5 \\
\hline Mining/Quarrying & 1,004 & 1.2 & 1.6 & 1.5 & 1.4 & 552 & 1.9 & 2.4 & 0.8 & 2.0 & 1.1 \\
\hline Manufacturing & 785 & 11.2 & 18.5 & 8.7 & 14.4 & 471 & 6.1 & 8.1 & 2.8 & 6.6 & 4.6 \\
\hline Electricity/Gas/Water & 1,098 & 0.1 & 0.9 & 1.0 & 0.6 & 592 & 0.1 & 0.3 & 0.3 & 0.2 & 7.7 \\
\hline Construction & 633 & 11.9 & 9.2 & 5.2 & 9.7 & 432 & 6.9 & 8.1 & 1.5 & 7.1 & 6.9 \\
\hline Trade/Hotel/Restaurant & 836 & 24.3 & 27.0 & 17.2 & 24.7 & 566 & 9.6 & 13.6 & 8.4 & 10.7 & 6.3 \\
\hline Transportation & 663 & 8.7 & 9.3 & 3.2 & 8.3 & 519 & 3.0 & 6.2 & 1.8 & 3.9 & 6.3 \\
\hline Information & 1,446 & 0.1 & 0.8 & 2.6 & 0.7 & 705 & 0.0 & 0.1 & 0.4 & 0.1 & 21.1 \\
\hline Finance/Real Estate & 1,315 & 0.2 & 1.6 & 5.8 & 1.6 & 832 & 0.0 & 0.5 & 1.5 & 0.2 & 6.7 \\
\hline Education Services & 1,079 & 0.3 & 1.6 & 18.2 & 3.3 & 780 & 0.1 & 1.6 & 40.6 & 2.0 & \\
\hline Health Services & 1,282 & 0.3 & 0.8 & 3.2 & 0.9 & 879 & 0.1 & 0.4 & 3.5 & 0.3 & 5.5 \\
\hline Government Services & 904 & 12.1 & 20.0 & 29.5 & 18.2 & 591 & 3.9 & 10.5 & 24.5 & 6.5 & \\
\hline Others & 881 & 1.5 & 1.3 & 0.8 & 1.3 & 445 & 0.7 & 0.8 & 0.5 & 0.7 & \\
\hline Total & 782 & 100.0 & 100.0 & 100.0 & 100.0 & 468 & 100.0 & 100.0 & 100.0 & 100.0 & 5.3 \\
\hline
\end{tabular}

(Note) Mean PCE refers to mean per capita expenditure.

(Source) Authors' calculation from Susenas in 2011 and Annual Statistics Indonesia in various years. 
Table 7. Decomposition of Expenditure Inequality by Education Subgroup in 2000 and 2011 in Indonesia: Tertiary Education in Urban Areas

\begin{tabular}{lrrrr}
\hline & Inequality & $\begin{array}{r}\text { Contribution } \\
(\%)\end{array}$ & $\begin{array}{r}\text { Expenditure Share } \\
(\%)\end{array}$ & $\begin{array}{r}\text { Mean Per Capita Exp. } \\
(1,000 \text { Rp. })\end{array}$ \\
\hline 2000 & & & & \\
D1, D2 and D3 & 0.231 & 28.8 & 28.6 & 272 \\
D4 and S1 & 0.216 & 62.4 & 66.4 & 321 \\
S2 and S3 & 0.279 & 6.0 & 5.0 & \\
W-subgroup & 0.223 & 97.2 & & \\
B-subgroup & 0.007 & 2.8 & 100.0 & \\
Total & 0.230 & 100.0 & & \\
\hline 2011 & & & 21.6 & 1,409 \\
D1, D2 and D3 & 0.403 & 29.0 & 67.0 & 1,560 \\
D4 and S1 & 0.260 & 58.2 & 11.4 & \\
S2 and S3 & 0.287 & 10.9 & & \\
W-subgroup & 0.294 & 98.1 & & \\
B-subgroup & 0.006 & 1.9 & & \\
Total & 0.300 & 100.0 & & \\
\hline
\end{tabular}

(Note) D1, D2, D3 and D4 are, respectively, Diploma 1, 2, 3 and 4, while S1, S2 and S3 are, respectively, bachelor, master's and doctoral degrees.

(Source) Authors' calculation from Susenas in 2000 and 2011.

Table 8. Decomposition of Expenditure Inequality by Age Groups in the Urban and Rural Sectors in 2012 in Myanmar

\begin{tabular}{|c|c|c|c|c|c|c|c|c|c|}
\hline \multirow{2}{*}{$\begin{array}{l}\text { Age } \\
\text { group }\end{array}$} & \multicolumn{3}{|c|}{ Primary } & \multicolumn{3}{|c|}{ Secondary } & \multicolumn{3}{|c|}{ Tertiary } \\
\hline & Theil T & $\begin{array}{r}\text { Contribution } \\
(\%) \\
\end{array}$ & $\begin{array}{r}\text { Population } \\
\text { Share (\%) }\end{array}$ & Theil T & $\begin{array}{r}\text { Contribution } \\
(\%)\end{array}$ & $\begin{array}{c}\text { Population } \\
\text { Share (\%) }\end{array}$ & Theil T & $\begin{array}{r}\text { Contribution } \\
(\%)\end{array}$ & $\begin{array}{r}\text { Population } \\
\text { Share (\%) }\end{array}$ \\
\hline-40 & 0.345 & 13 & 20 & 0.408 & 16 & 19 & 0.779 & 31 & 24 \\
\hline $41-50$ & 0.459 & 22 & 27 & 0.479 & 26 & 26 & 0.636 & 24 & 26 \\
\hline $51-60$ & 0.592 & 31 & 28 & 0.503 & 28 & 28 & 0.602 & 20 & 25 \\
\hline $61-$ & 0.704 & 34 & 25 & 0.581 & 30 & 27 & 0.799 & 24 & 25 \\
\hline W-group & 0.536 & 100 & & 0.497 & 100 & & 0.704 & 99 & \\
\hline B-group & 0.001 & 0 & & 0.001 & 0 & & 0.006 & 1 & \\
\hline Total & 0.537 & 100 & 100 & 0.498 & 100 & 100 & 0.710 & 100 & 100 \\
\hline
\end{tabular}

\begin{tabular}{|c|c|c|c|c|c|c|}
\hline \multirow{2}{*}{$\begin{array}{l}\text { Age } \\
\text { group }\end{array}$} & \multicolumn{3}{|c|}{ Pre-primary } & \multicolumn{3}{|c|}{ Primary } \\
\hline & Theil T & $\begin{array}{r}\text { Contribution } \\
(\%) \\
\end{array}$ & $\begin{array}{c}\text { Population } \\
\text { Share (\%) }\end{array}$ & Theil T & $\begin{array}{r}\text { Contribution } \\
(\%) \\
\end{array}$ & $\begin{array}{r}\text { Population } \\
\text { Share (\%) } \\
\end{array}$ \\
\hline-40 & 0.393 & 14 & 19 & 0.309 & 25 & 27 \\
\hline $41-50$ & 0.383 & 20 & 24 & 0.283 & 27 & 30 \\
\hline $51-60$ & 0.524 & 35 & 26 & 0.357 & 34 & 29 \\
\hline $61-$ & 0.441 & 30 & 30 & 0.298 & 14 & 15 \\
\hline W-group & 0.444 & 99 & & 0.314 & 100 & \\
\hline B-group & 0.003 & 1 & & 0.001 & 0 & \\
\hline Total & 0.447 & 100 & 100 & 0.315 & 100 & 100 \\
\hline
\end{tabular}

(Source) Authors' calculation from HIES in 2006 and 2012. 
Figure 1. Gross Enrollment Ratio, Secondary Education

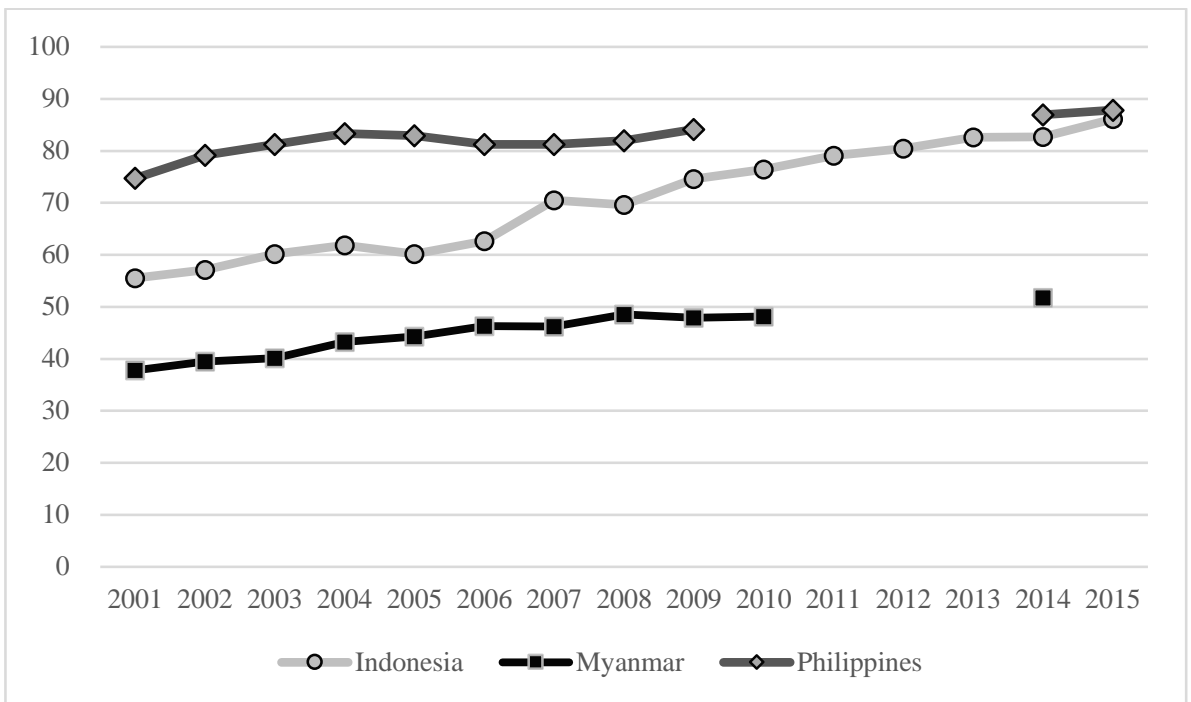

(Source) World Development Indicators, World Bank.

Figure 2. Gross Enrollment Ratio, Tertiary Education

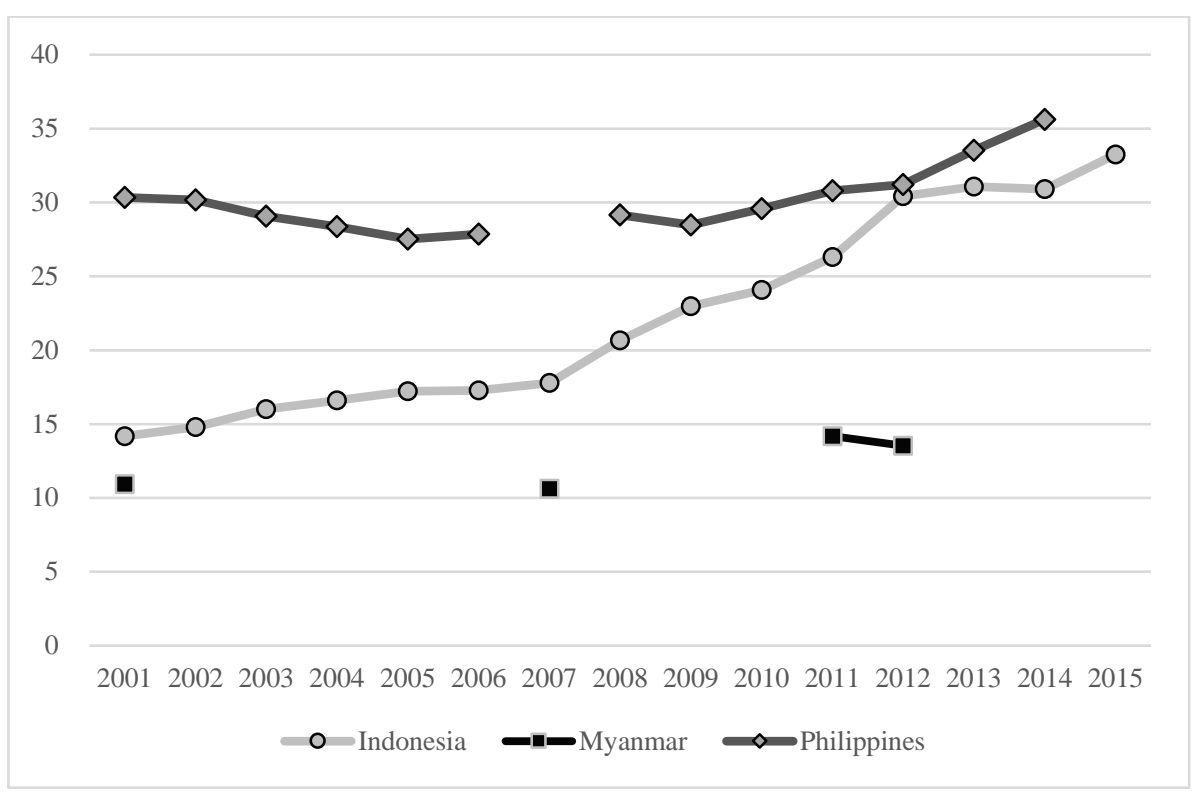

(Source) World Development Indicators, World Bank. 


\section{Appendix}

Table A1. Years of Education

\begin{tabular}{|c|c|c|}
\hline & Education & Years of education \\
\hline \multicolumn{3}{|l|}{ Indonesia } \\
\hline \multirow{3}{*}{ Primary } & No education & 0 \\
\hline & Incomplete primary education & 3 \\
\hline & General and Islamic primary education & 6 \\
\hline \multirow{2}{*}{ Secondary } & General and Islamic junior secondary education & 9 \\
\hline & General, Islamic and vocational senior secondary education & 12 \\
\hline \multirow{4}{*}{ Tertiary } & Diploma I and II programs & 13 \\
\hline & Diploma III programs & 15 \\
\hline & Diploma IV or bachelor's degree programs & 16 \\
\hline & Master's or doctor's degree programs & 18 \\
\hline \multicolumn{3}{|l|}{ Myanmar } \\
\hline No education & No education (illiterate) & 0 \\
\hline \multirow{3}{*}{ Pre-primary } & No education (literate) & 1 \\
\hline & Monastic education & 2 \\
\hline & Incomplete primary education & 4 \\
\hline Primary & Primary education & 5 \\
\hline \multirow{2}{*}{ Secondary } & Junior secondary education & 9 \\
\hline & Senior secondary education & 11 \\
\hline \multirow{2}{*}{ Tertiary } & Vocational education & 13 \\
\hline & Bachelor's, master's and doctor's degree programs & 14 \\
\hline \multicolumn{3}{|l|}{ Philippines } \\
\hline \multirow{3}{*}{ Primary } & No education & 0 \\
\hline & Pre-primary education & 3 \\
\hline & Primary education & 6 \\
\hline \multirow{2}{*}{ Secondary } & Incomplete secondary education & 8 \\
\hline & Secondary education & 10 \\
\hline \multirow{3}{*}{ Tertiary } & Technical and vocational education & 12 \\
\hline & Bachelor's degree programs & 14 \\
\hline & Master's or doctor's degree programs & 16 \\
\hline
\end{tabular}

(Sources) Susenas for Indonesia, HIES for Myanmar, and FIES for the Philippines. 
Table A2a. Hierarchical versus Non-hierarchical Decomposition of Expenditure Inequality, Indonesia

\begin{tabular}{|c|c|c|c|c|}
\hline & \multicolumn{2}{|c|}{ Hierarchical Decomposition } & \multicolumn{2}{|c|}{ Non-hierarchical Decomposition } \\
\hline & Theil T & Contribution (\%) & Theil T & Contribution (\%) \\
\hline \multicolumn{5}{|l|}{2000} \\
\hline Total & 0.200 & 100.0 & 0.200 & 100.0 \\
\hline B-sector (BS) & 0.030 & 14.9 & 0.030 & 14.9 \\
\hline B-group (BG) & & & 0.038 & 19.0 \\
\hline Interaction Term (ISG) & & & -0.016 & -8.2 \\
\hline W-sector B-group (WSBG) & 0.022 & 10.8 & & \\
\hline W-sector W-group (WSWG) & 0.149 & 74.3 & 0.149 & 74.3 \\
\hline \multicolumn{5}{|l|}{2006} \\
\hline Total & 0.248 & 100.0 & 0.248 & 100.0 \\
\hline B-sector (BS) & 0.044 & 17.7 & 0.044 & 17.7 \\
\hline B-group (BG) & & & 0.057 & 23.2 \\
\hline Interaction Term (ISG) & & & -0.024 & -9.6 \\
\hline W-sector B-group (WSBG) & 0.034 & 13.6 & & \\
\hline W-sector W-group (WSWG) & 0.171 & 68.7 & 0.171 & 68.7 \\
\hline \multicolumn{5}{|l|}{2011} \\
\hline Total & 0.322 & 100.0 & 0.322 & 100.0 \\
\hline B-sector (BS) & 0.034 & 10.4 & 0.034 & 10.4 \\
\hline B-group (BG) & & & 0.075 & 23.4 \\
\hline Interaction Term (ISG) & & & -0.021 & -6.4 \\
\hline W-sector B-group (WSBG) & 0.054 & 17.0 & & \\
\hline W-sector W-group (WSWG) & 0.233 & 72.6 & 0.233 & 72.6 \\
\hline
\end{tabular}

(Source) Authors' calculation from Susenas in 2000, 2006 and 2011.

Table A2b. Hierarchical versus Non-hierarchical Decomposition of Expenditure Inequality, Myanmar

\begin{tabular}{|c|c|c|c|c|}
\hline & \multicolumn{2}{|c|}{ Hierarchical Decomposition } & \multicolumn{2}{|c|}{ Non-hierarchical Decomposition } \\
\hline & Theil $\mathrm{T}$ & Contribution (\%) & Theil T & Contribution (\%) \\
\hline \multicolumn{5}{|l|}{2006} \\
\hline Total & 0.400 & 100.0 & 0.400 & 100.0 \\
\hline B-sector (BS) & 0.006 & 1.6 & 0.006 & 1.6 \\
\hline B-group (BG) & & & 0.017 & 4.3 \\
\hline Interaction Term (ISG) & & & -0.003 & -0.9 \\
\hline W-sector B-group (WSBG) & 0.014 & 3.4 & & \\
\hline W-sector W-group (WSWG) & 0.380 & 95.0 & 0.380 & 95.0 \\
\hline \multicolumn{5}{|l|}{2012} \\
\hline Total & 0.520 & 100.0 & 0.520 & 100.0 \\
\hline B-sector (BS) & 0.028 & 5.3 & 0.028 & 5.3 \\
\hline B-group (BG) & & & 0.040 & 7.7 \\
\hline Interaction Term (ISG) & & & -0.016 & -3.0 \\
\hline W-sector B-group (WSBG) & 0.024 & 4.7 & & \\
\hline W-sector W-group (WSWG) & 0.468 & 90.0 & 0.468 & 90.0 \\
\hline
\end{tabular}

(Source) Authors' calculation from HIES in 2006 and 2012. 
Table A2c. Hierarchical versus Non-hierarchical Decomposition of Expenditure Inequality, Philippines

\begin{tabular}{|c|c|c|c|c|}
\hline & \multicolumn{2}{|c|}{ Hierarchical Decomposition } & \multicolumn{2}{|c|}{ Non-hierarchical Decomposition } \\
\hline & Theil T & Contribution (\%) & Theil T & Contribution (\%) \\
\hline \multicolumn{5}{|l|}{2000} \\
\hline Total & 0.438 & 100.0 & 0.438 & 100.0 \\
\hline B-sector (BS) & 0.076 & 17.3 & 0.076 & 17.3 \\
\hline B-group (BG) & & & 0.129 & 29.6 \\
\hline Interaction Term (ISG) & & & -0.046 & -10.5 \\
\hline W-sector B-group (WSBG) & 0.083 & 19.0 & & \\
\hline W-sector W-group (WSWG) & 0.279 & 63.7 & 0.279 & 63.7 \\
\hline \multicolumn{5}{|l|}{2006} \\
\hline Total & 0.391 & 100.0 & 0.391 & 100.0 \\
\hline B-sector (BS) & 0.068 & 17.4 & 0.068 & 17.4 \\
\hline B-group (BG) & & & 0.112 & 28.6 \\
\hline Interaction Term (ISG) & & & -0.040 & -10.3 \\
\hline W-sector B-group (WSBG) & 0.071 & 18.3 & & \\
\hline W-sector W-group (WSWG) & 0.251 & 64.3 & 0.251 & 64.3 \\
\hline
\end{tabular}

(Source) Authors' calculation from FIES in 2000 and 2006.

Table A3a. Expenditure Shares of Decile Groups in Urban and Rural Sectors in Indonesia (in \%)

\begin{tabular}{|c|c|c|c|c|c|c|c|c|c|}
\hline \multirow[b]{2}{*}{ Decile } & \multicolumn{3}{|c|}{ Urban } & \multicolumn{3}{|c|}{ Rural } & \multicolumn{3}{|c|}{ Total } \\
\hline & 2000 & 2011 & Change & 2000 & 2011 & Change & 2000 & 2011 & Change \\
\hline 1 & 3.6 & 2.8 & -0.81 & 4.5 & 3.7 & -0.83 & 3.8 & 3.0 & -0.87 \\
\hline 2 & 4.8 & 3.7 & -1.05 & 5.9 & 4.7 & -1.14 & 5.1 & 3.9 & -1.12 \\
\hline 3 & 5.7 & 4.6 & -1.11 & 6.8 & 5.6 & -1.20 & 5.9 & 4.8 & -1.14 \\
\hline 4 & 6.5 & 5.5 & -1.03 & 7.5 & 6.4 & -1.10 & 6.7 & 5.6 & -1.08 \\
\hline 5 & 7.4 & 6.5 & -0.89 & 8.4 & 7.4 & -0.91 & 7.5 & 6.6 & -0.94 \\
\hline 6 & 8.4 & 7.8 & -0.65 & 9.2 & 8.6 & -0.65 & 8.5 & 7.8 & -0.74 \\
\hline 7 & 9.8 & 9.4 & -0.33 & 10.3 & 10.0 & -0.31 & 9.8 & 9.3 & -0.45 \\
\hline 8 & 11.6 & 11.8 & 0.17 & 11.8 & 11.9 & 0.15 & 11.5 & 11.5 & -0.01 \\
\hline 9 & 14.7 & 15.7 & 1.04 & 14.1 & 14.8 & 0.78 & 14.4 & 15.3 & 0.90 \\
\hline 10 & 27.6 & 32.3 & 4.66 & 21.6 & 26.8 & 5.22 & 26.8 & 32.2 & 5.45 \\
\hline T20/B20 & 5.1 & 7.4 & & 3.4 & 5.0 & & 4.6 & 6.9 & \\
\hline
\end{tabular}

(Note) T20/B20 is the ratio of the share of the top $20 \%$ to the share of the bottom $20 \%$.

(Source) Authors' calculation from Susenas in 2000 and 2011. 
Table A3b. Expenditure Shares of Decile Groups in Urban and Rural Sectors in Myanmar (in \%)

\begin{tabular}{|c|c|c|c|c|c|c|c|c|c|}
\hline \multirow[b]{2}{*}{ Decile } & \multicolumn{3}{|c|}{ Urban } & \multicolumn{3}{|c|}{ Rural } & \multicolumn{3}{|c|}{ Total } \\
\hline & 2006 & 2012 & Change & 2006 & 2012 & Change & 2006 & 2012 & Change \\
\hline & 2.2 & 1.7 & -0.43 & 2.4 & 2.3 & -0.19 & 2.3 & 2.0 & -0.34 \\
\hline 2 & 3.3 & 2.8 & -0.50 & 3.7 & 3.5 & -0.27 & 3.6 & 3.1 & -0.48 \\
\hline 3 & 4.2 & 3.7 & -0.47 & 4.7 & 4.3 & -0.38 & 4.5 & 3.9 & -0.57 \\
\hline & 5.1 & 4.7 & -0.41 & 5.6 & 5.2 & -0.42 & 5.4 & 4.8 & -0.59 \\
\hline & 6.0 & 5.7 & -0.36 & 6.6 & 6.2 & -0.40 & 6.4 & 5.8 & -0.54 \\
\hline ( & 7.2 & 6.9 & -0.24 & 7.9 & 7.5 & -0.41 & 7.6 & 7.0 & -0.55 \\
\hline & 8.7 & 8.5 & -0.15 & 9.4 & 9.0 & -0.41 & 9.0 & 8.6 & -0.41 \\
\hline$\varepsilon$ & 11.0 & 10.7 & -0.30 & 11.4 & 11.3 & -0.11 & 11.2 & 11.1 & -0.09 \\
\hline s & 14.8 & 14.6 & -0.19 & 15.1 & 15.5 & 0.38 & 15.0 & 15.1 & 0.14 \\
\hline 10 & 37.6 & 40.7 & 3.04 & 33.1 & 35.3 & 2.23 & 35.2 & 38.6 & 3.43 \\
\hline T20/B20 & 9.5 & 12.1 & & 7.8 & 8.9 & & 8.5 & 10.6 & \\
\hline
\end{tabular}

(Note) T20/B20 is the ratio of the share of the top 20\% to the share of the bottom $20 \%$.

(Source) Authors' calculation from HIES in 2006 and 2012.

Table A3c. Expenditure Shares of Decile Groups in Urban and Rural Sectors in the Philippines (in \%)

\begin{tabular}{|c|c|c|c|c|c|c|c|c|c|}
\hline \multirow[b]{2}{*}{ Decile } & \multicolumn{3}{|c|}{ Urban } & \multicolumn{3}{|c|}{ Rural } & \multicolumn{3}{|c|}{ Total } \\
\hline & 2000 & 2006 & Change & 2000 & 2006 & Change & 2000 & 2006 & Change \\
\hline 1 & 2.1 & 2.2 & 0.09 & 3.0 & 3.0 & 0.02 & 2.1 & 2.2 & 0.06 \\
\hline 2 & 3.3 & 3.4 & 0.12 & 4.2 & 4.1 & -0.07 & 3.1 & 3.1 & 0.05 \\
\hline 3 & 4.2 & 4.4 & 0.19 & 5.0 & 5.0 & -0.09 & 3.9 & 4.0 & 0.07 \\
\hline 4 & 5.1 & 5.4 & 0.25 & 5.9 & 5.8 & -0.07 & 4.8 & 4.9 & 0.09 \\
\hline 5 & 6.2 & 6.5 & 0.31 & 6.9 & 6.7 & -0.11 & 5.9 & 6.0 & 0.11 \\
\hline 6 & 7.5 & 7.8 & 0.29 & 8.0 & 7.9 & -0.13 & 7.2 & 7.4 & 0.17 \\
\hline 7 & 9.2 & 9.5 & 0.31 & 9.6 & 9.4 & -0.23 & 9.0 & 9.2 & 0.24 \\
\hline 8 & 11.6 & 11.9 & 0.29 & 11.8 & 11.6 & -0.23 & 11.6 & 11.8 & 0.27 \\
\hline 9 & 15.7 & 16.0 & 0.24 & 15.6 & 15.5 & -0.14 & 16.1 & 16.4 & 0.37 \\
\hline 10 & 35.0 & 32.9 & -2.10 & 30.1 & 31.1 & 1.05 & 36.5 & 35.1 & -1.42 \\
\hline T20/B20 & 9.4 & 8.8 & & 6.4 & 6.6 & & 10.1 & 9.7 & \\
\hline
\end{tabular}

(Note) T20/B20 is the ratio of the share of the top 20\% to the share of the bottom $20 \%$. (Source) Authors' calculation from FIES in 2000 and 2006. 